\title{
Seismic performance of steel moment and hinged frames with rocking shear walls
}

\author{
Mehrdad Piri \\ Kharazmi University
}

Ali Massumi ( $\nabla$ ali.massumi@gmail.com )

Kharazmi University https://orcid.org/0000-0003-4636-6553

\section{Research Article}

Keywords: Repairable structure, Limited damage, Rocking motion, Self-centering, Time history analysis

Posted Date: July 30th, 2021

DOl: https://doi.org/10.21203/rs.3.rs-727665/v1

License: (9) This work is licensed under a Creative Commons Attribution 4.0 International License. Read Full License

Version of Record: A version of this preprint was published at Journal of Building Engineering on February 1st, 2022. See the published version at https://doi.org/10.1016/j.jobe.2022.104121. 


\title{
Seismic performance of steel moment and hinged frames with rocking shear walls
}

Mehrdad Piri, Master graduate of Structural Engineering, Kharazmi University Postal address: Kharazmi University, No.43, Dr. Mofatteh Ave., Tehran, IRAN ORCID iD: $\underline{0000-0001-9601-1158}$

Ali Massumi, Professor of Structural Engineering, Kharazmi University Postal address: Kharazmi University, No.43, Dr. Mofatteh Ave., Tehran, IRAN ORCID iD: 0000-0003-4636-6553

Corresponding author: Ali Massumi Email address: massumi@khu.ac.ir Telephone: +982188830891

\begin{abstract}
The addition of a rocking structural system will soften the connection between a foundation and superstructure and help the beam-column connections to become softer than typical ones. These structures, with the addition of rocking structural systems, follow the elastic gap opening mechanism to soften the structural seismic response. Post-tensioned energy dissipating devices and dampers are used in rocking systems to enable the structure to return to its initial position (self-centering) and to dissipate seismic energy, respectively. The current study investigated the use of a rocking shear wall system in steel moment-resistant and hinged frames and determined the amount of damage and the economic effects on the structures. For this purpose, 3D models of 3-, 9-, and 20-story SAC-project steel frames were modeled and validated according to FEMA$355 \mathrm{C}$ and then a hybrid rocking shear wall was added to them. The structures were designed and modeled according to common seismic codes and were analyzed using nonlinear time history when subjected to a series of records from FEMA-355C. The results showed that the use of a hinged frame attached to a rocking concrete shear wall (HFR) increased the fundamental period and inter-story displacement and decreased the amount of steel used in the 3-, 9-, and 20-story models compared to similar models with fixed connections in moment frames (MFR). The HFR shear wall models exhibited better seismic performance than MFR models, which increased their load-bearing capacity and reduced their weight, which reduced construction costs.
\end{abstract}

Keywords: Repairable structure, Limited damage, Rocking motion, Self-centering, Time history analysis 


\section{Introduction}

A common problem with typical buildings is failure of the fixed connections, especially column-foundation connections. During an earthquake, these fixed connections will absorb a large amount of energy and can experience severe damage. Because repairing a foundation under a structure is both difficult and expensive, it has been proposed that the columns not be fixed to the foundation. In modern low-damage systems, the columns are not fixed to the foundation and the frame is allowed to uplift and rock. This makes the structure softer and more ductile and increases the fundamental period of the structure, which will cause it to absorb less seismic force. Such structural systems are usually self-centering and feature energy dissipation. These properties are related to the weight of the structure and the addition of devices such as post-tensioned cables, viscoelastic or frictional vertical dampers, and elastic bearings.

During the 1960 Chile earthquake, reinforced concrete air tanks which were apparently stable were severely damaged. In 1963, Housner [1] conducted the first rocking motion time analysis of structures and found that several types of elevated water tank were able to survive earthquakes, despite their unstable appearance. Since the 1970s, the rocking motion principle has been widely used to investigate the seismic resistance of structural systems. Hucklebridge and Clough [2,3] studied the effects of allowable column uplift in steel frames on their seismic response under severe seismic loading. The experimental results showed that the column uplift in these frames significantly reduced the seismic loading and ductility demand. Priestley et al. [4] verified the energy dissipation mechanism of the rocking structural systems in shaking table experiments. They proposed a simple design method for assessing maximum rocking displacement using the equivalent elastic properties and the response-spectra method. The seismic response analysis of rocking structures under lateral earthquake loading was studied before the 1980s [5-8].

Since the 1990s, after completion of the theoretical mechanism analysis of the seismic response of rocking structures, experimental studies were carried out on engineering structural systems, including bridges and buildings. Kurama [9] used models of double-rocking prefabricated concrete shear walls with friction dampers on each floor between the walls to significantly reduce the lateral displacement using a relative slip displacement mechanism in the rocking system. Nonlinear static analysis showed that significantly large sliding displacement occurred in these dampers without causing much damage to the walls.

Burtscher and Dorfmann [10] determined that elastomeric bearings have different shear stiffnesses in the principal in-plane directions at different slope angles. They subjected the bearings to a series of compression and shear tests and the corresponding results were compared. It was shown that the new concept provided a valuable alternative for elastomeric bearings. The ratio of the shear stiffness in the two principal in-plane directions could be used as a design parameter to maximize the benefit provided by elastomeric bearings for the seismic isolation of structures.

A parametric study on multiple walls was conducted by Xiaobin et al. [11] to evaluate the effect of different factors on the hysteretic behavior of hybrid self-centering walls. They examined a self-centering rocking wall model comprised of a concrete rocking wall, post-tensioned cables, and wall-footing dampers. The results showed that the greater the distance between the cables, the greater the energy dissipation and that the greater the cable yield strength, the greater the energy dissipation. It also was observed that increasing the cross-section of the cables rapidly increased the wall resistance, which ultimately increased the wall-footing damper stiffness, and slightly increased the wall stiffness. They concluded that, with the selection of the correct values for the design, the hybrid rocking wall can provide a satisfactory energy dissipation capacity while experiencing little residual deformation after unloading. The 
cross-sectional area and the cable yield strength had the greatest effect on the hysteretic behavior of hybrid selfcentering walls.

Guo et al. [12] proposed a model of a self-centering concrete wall with friction components to provide seismic resilience in structures. Self-centering was provided by vertical post-tensioned cables along the wall and two steel jackets at the footwalls were employed to protect them from destruction and cracking caused by the rocking motion. Repairable friction dampers between the wall and hinged columns also were used to dissipate energy. Their wall model showed good capacity for self-centering and energy dissipation. Under cyclic loading with the greatest opening angle, the main structure remained linear and it was observed that substantial pressure was applied to the footwalls.

Massumi et al. [13] removed several plan columns and suspended the floors using tuned mass dampers (TMD) and Vierendeel girders in a 10-story model. They concluded that these dampers absorbed and dissipated the vibrations of the structure and significantly reduced the acceleration and displacement of the steel structure. They also concluded that this approach protected the structure against loading caused by explosions, severe ground motions, and other uncommon environmental loads without adding significant mass to the structure or disturbing the architectural design, which are notable advantages of this approach.

Both 5- and 10-story 3D moment resisting frames with hinged and fixed support connections at base level were modeled and compared by Mohammadi et al. [13]. The results indicated that the use of hinged support connections instead of fixed ones improved the ductile behavior of the structures and prevented column-base failure, especially at the corners. In this approach, the beams were more likely to be damaged before the columns.

A repairable rocking shear wall with replaceable footwalls was proposed by Chen et al. [14] and was compared to a common coupled shear wall. These replaceable elements were designed to withstand plastic deformation and the bolt connection at the bottom plate could be easily replaced by loosening the connection bolts. Because the footings were made of rubber, they could only withstand pressure, but the addition of several steel plates increased their ability to withstand tension and provided shear strength. The results showed that the lower corners of the typical shear wall sustained damage, while the damage to the proposed shear walls was concentrated in the replaceable footwall elements.

Huang et al. [15] proposed a model of a rocking shear wall with post-tensioned cables and energy-dissipative vertical friction dampers. These elements were used to provide self-centering and seismic energy dissipation to maintain the structure in the linear domain. The effects of the damper and cable parameters on the lateral response were investigated using the proposed analytical model. The results showed that increasing the initial stress of posttensioned cables improved the wall self-centering performance and increased its capacity and the lateral strength of the wall. They concluded that, in order to increase the energy dissipation capacity of the wall, its self-centering capacity should be ensured and then the activation force of the dampers should be increased. It was also concluded that changing the stiffness of the dampers had little effect on the lateral response of the wall.

Hashemi and Quenneville [16] proposed a rocking, low-damage, cross-laminated timber shear wall with a frictionbased energy dissipation device located at wall footings which could be tuned to improve the self-centering capacity of the wall and absorb the imposed seismic energy. Slotted center plates, friction bolts with disc springs, stiffeners, and die springs were used in this friction device to provide energy dissipation. The wall was subjected to cyclic displacement control and large-scale cyclic tests. The results demonstrated repeatable hysteretic performance without 
any stiffness degradation that confirmed the low damage characteristic of the wall. It also was observed that the friction device worked as a fuse to provide nonlinear behavior and, as a result, the rest of the system remained elastic with no significant damage.

Leikune F.Aragaw and Paolo M.Calvi [17] investigated the performance of rocking shear wall structures and analyzed them under compatible earthquakes via non-linear time-history analyses. The results showed that the rocking shear wall structures are superior to traditional shear walls as they do not suffer severe damages and are capable of going back to their initial position. It was also revealed that taller structures are more likely to be affected by the higher modes to a greater extent compared to traditional reinforced concrete structures.

Xiangmin Li et al. [18] proposed a new ESRW (externally-hung self-centering rocking wall) structural system to retrofit existing structures. The proposed rocking wall was connected to the concrete structure through reinforced corbels which are installed on the adjacent columns using H-shaped connectors. The model then was investigated through a series of shaking table tests to evaluate the seismic performance and self-centering ability of the new system. The results revealed that the damage, the maximum story drift and the residual deformation of the ESRW structural system was significantly reduced compared to the structure without the rocking wall and the ESRW structure exhibited desirable self-centering characteristics during the tests.

The present study investigated the seismic performance, amount of damage, and economic aspects of the proposed hybrid-concrete rocking shear wall for steel moment and hinged frames. This wall consisted of friction dampers, elastic foot bearings, and post-tensioned cables and was allowed to rock at its heels. Section 2 provides a brief description of the SAC-project properties. The dynamic specifications of the model buildings in Los Angeles were verified and compared according to FEMA-355C [19] and the performance of the two systems in the buildings was assessed using 14 pairs of near-field earthquake records.

\section{Modeling}

\subsection{Verification}

In this study, three-dimensional 3-, 9-, and 20-story office buildings having SAC-project steel frames were used as representative of low, mid-height, and high-rise buildings, respectively. These buildings were located in Los Angeles in a region of high seismicity on stiff soil type II. The buildings were modeled and then the two systems were added to each model. In the first system, all the connections in the hinged frame were assumed to be hinged, then the frame was added to a hybrid concrete rocking shear wall. In the second system, all connections in the moment frame were assumed to be fixed, then the frame was added to a wall having the same properties of the first system. The performance, amount of damage, and economic aspects of the systems then were compared.

The load patterns used were according to FEMA-355C, appendix B, for the following floor load distributions: Calculated floor dead load for weight: $96 \mathrm{psf}\left(469 \mathrm{~kg} / \mathrm{m}^{2}\right)$; roof dead load, excluding penthouse: $83 \mathrm{psf}\left(405 \mathrm{~kg} / \mathrm{m}^{2}\right)$, penthouse dead load: $116 \mathrm{psf}\left(566 \mathrm{~kg} / \mathrm{m}^{2}\right)$; reduced live load per floor and roof: $20 \mathrm{psf}\left(98 \mathrm{~kg} / \mathrm{m}^{2}\right)$. The loading for all the structural models was constant. The structures used either A36 ksi beams with a nominal strength of $36 \mathrm{ksi}$ (2530 $\left.\mathrm{kg} / \mathrm{cm}^{2}\right)$ and an expected strength of $49.2 \mathrm{ksi}\left(3460 \mathrm{~kg} / \mathrm{cm}^{2}\right)$ or A572 Gr. $50 \mathrm{ksi}$ columns with a nominal strength of $50 \mathrm{ksi}\left(3515 \mathrm{~kg} / \mathrm{cm}^{2}\right)$ and an expected strength of $57.6 \mathrm{ksi}\left(4050 \mathrm{~kg} / \mathrm{cm}^{2}\right)$. The floor plans for the buildings were preset, as shown in Fig. 1. The shaded area indicates the penthouse. 

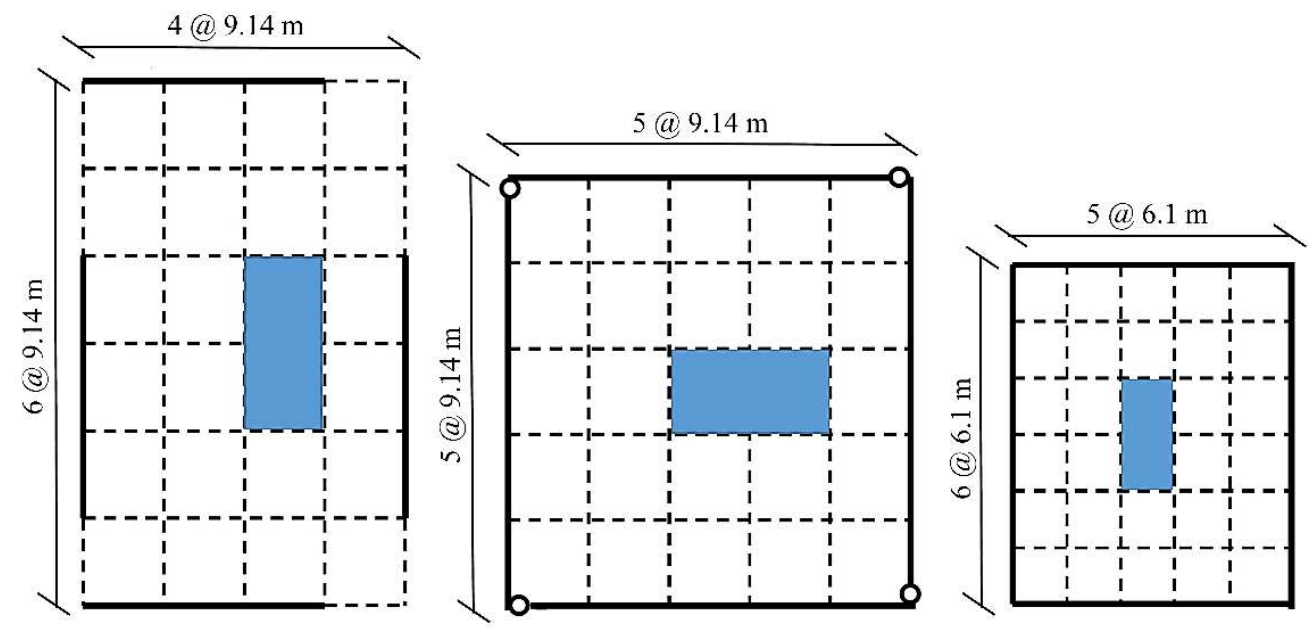

Fig. 1. Floor plans showing layout of moment-resisting frames for model buildings [19]

The models were designed in SAP2000 V14.2.2. The results, including the fundamental period and modal mass participation ratios are summarized in Table 1 . As seen, the verification results showed that the models were reasonably consistent with the SAC project results and had acceptable error.

Table 1. Verified modal properties of 3-, 9-, and 20-story SAC building models

\begin{tabular}{|c|c|c|c|c|}
\hline \multirow{2}{*}{ Modes } & \multicolumn{2}{|c|}{ SAC } & \multicolumn{2}{|c|}{ This Study } \\
\hline & Period (s) & Modal mass (\%) & Period (s) & Modal mass (\%) \\
\hline \multicolumn{5}{|c|}{ Los Angeles 3-Story } \\
\hline first & 1.03 & 82.8 & 1.04 & 81 \\
\hline second & 0.33 & 13.5 & 0.33 & 14 \\
\hline third & 0.17 & 3.7 & 0.17 & 4.2 \\
\hline \multicolumn{5}{|c|}{ Los Angeles 9-Story } \\
\hline first & 2.34 & 83.5 & 2.35 & 82 \\
\hline second & 0.88 & 10.6 & 0.87 & 11 \\
\hline third & 0.50 & 3.6 & 0.50 & 3.9 \\
\hline \multicolumn{5}{|c|}{ Los Angeles 20-Story } \\
\hline first & 3.98 & 80.4 & 3.94 & 78 \\
\hline second & 1.36 & 11.5 & 1.36 & 11 \\
\hline third & 0.79 & 3.4 & 0.79 & 3.9 \\
\hline
\end{tabular}

\subsection{Modeling wall components}

Next, the verified models (sect. 2.1) were added to a rocking shear wall. The hybrid rocking shear wall model used was a combined model consisting of cables, friction dampers, elastic wall-footings, and a concrete wall with the ability to uplift and rock. Two shear walls were designed which were coupled by friction dampers to provide energy dissipation, as recommended by Kurama [9]. Fig. 2 shows how these friction dampers, wall-footings and cables work together to control the lateral displacement of the walls by using slip displacement mechanism. 


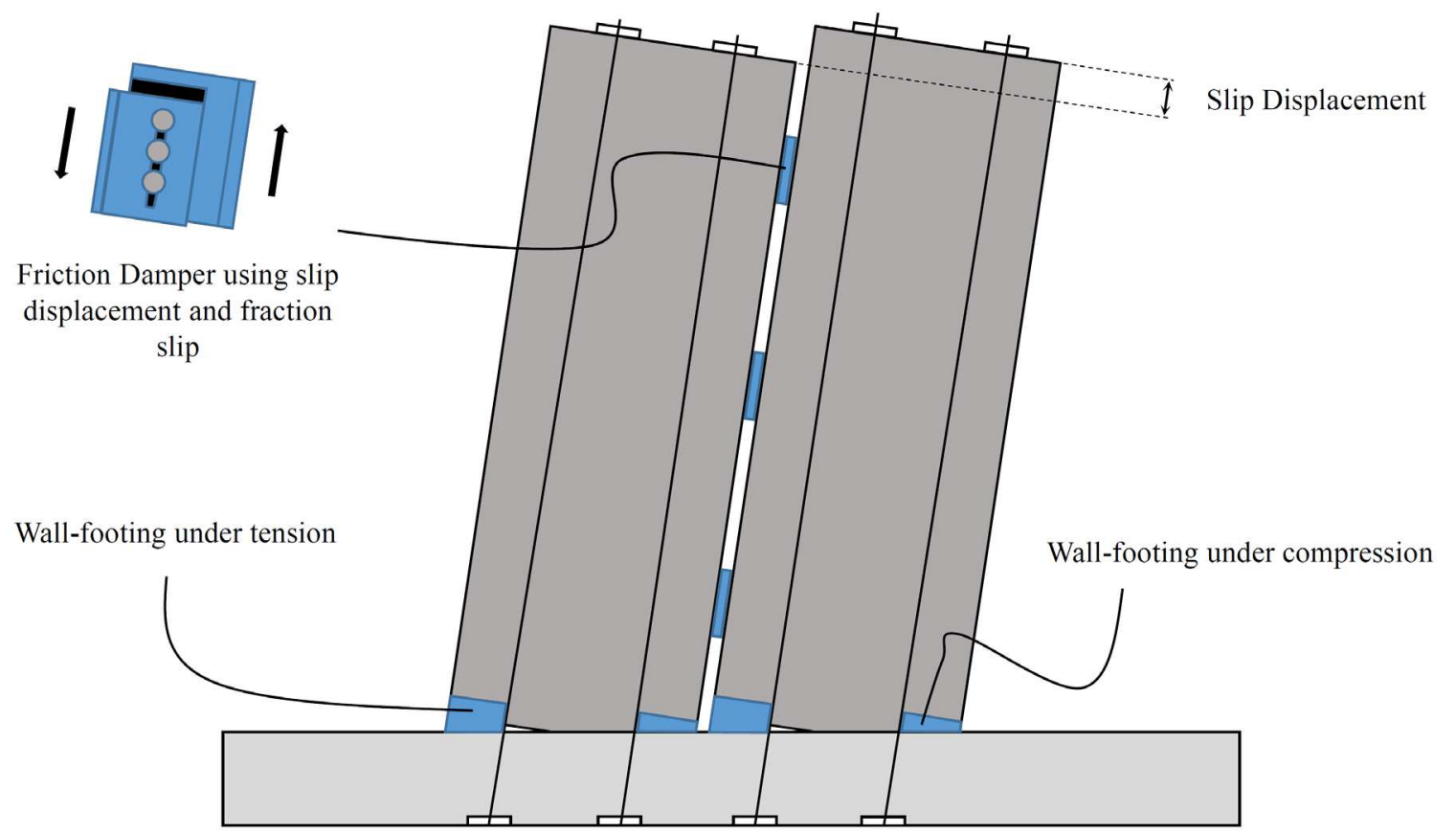

Fig. 2. Deformed shape of the proposed hybrid rocking shear wall model and components

In accordance with the material tests conducted by Gou et al. [12], the cables had a modulus of elasticity of $1,988,454 \mathrm{~kg} \cdot \mathrm{cm}^{2}$ and a mean yield strength of $15,275 \mathrm{~kg} \cdot \mathrm{cm}^{2}$ and were used in the present study. The cross-section of a single cable used in the 3-, 9-, and 20-story models was $25.8 \mathrm{~cm}^{2}$ in accordance with Xiaobin et al. [11], there were a total of 4,8 , and 8 cables with pre-stressed relative lengths of $97 \%, 97 \%$, and $98.5 \%$, respectively, in every single wall in the 3-, 9-, and 20-story wall models. To calculate the relative lengths of the pre-stressed cables, the beam and column sections were designed and then the models were analyzed under several earthquake motions. The forces on the cables were recorded and the strains were obtained from the stress-strain equation.

In accordance with the results from Huang et al. [15], the stiffness of the friction dampers was $200 \mathrm{kN} / \mathrm{mm}(20,394$ $\mathrm{kg} / \mathrm{m}^{2}$ ). The friction dampers were designed to resist displacement in three directions and only one damper, that could be easily replaced if damaged, was placed between the walls in each story. This friction device consisted of two steel angles and one T-steel which were bolted to the walls. Two friction plates (brass plates) were attached to the two inner surfaces of the steel angles and two high-strength bolts were used to provide energy dissipation.

Fig. 3 shows the 3-HFR model, details of the wall components proposed in this study and how they are connected. In this model, the connection of the columns to the foundation are assumed to be simple (Hinged base connection) and all of the beams are released at both ends (Hinged joints), while in the 3-MFR model as shown in Fig. 4, the connection of the columns to the foundation and the beams to the columns are assumed to be fixed as in conventional moment frames. 


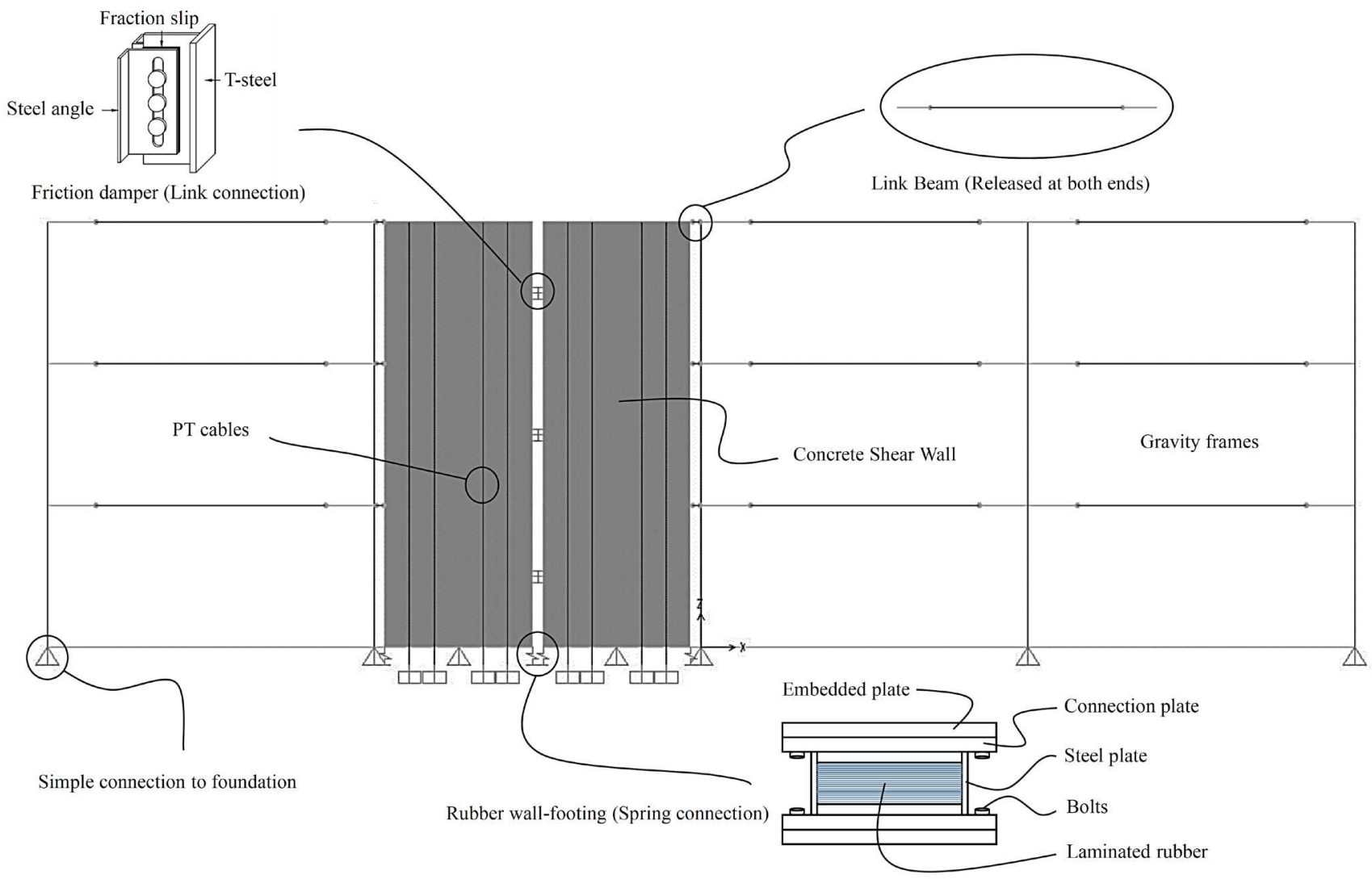

Fig. 3. Elevation view, undeformed shape of the 3-HFR model and details of the connections

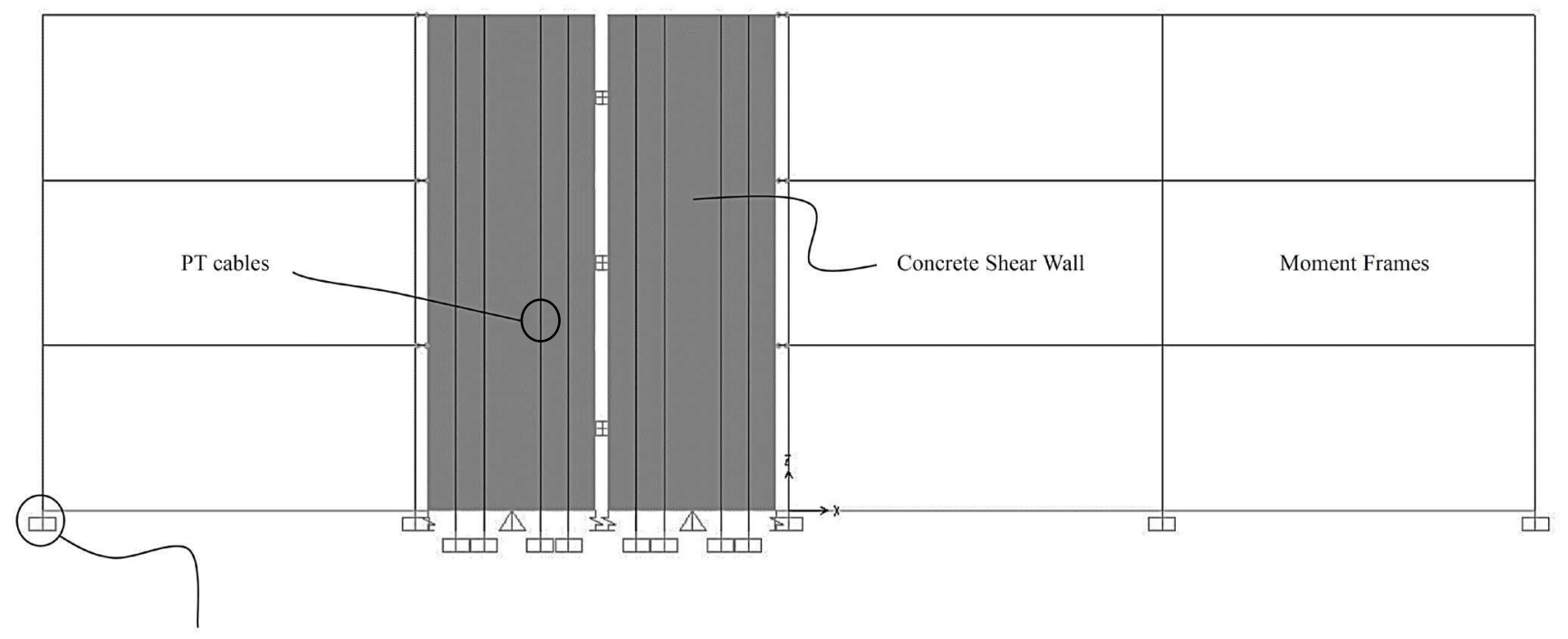

Fixed connection to foundation

Fig. 4. Elevation view and undeformed shape of the 3-MFR model 
All the connection details and modeling of all the components of the rocking shear wall proposed in the study are considered the same in each series of models, i.e. HFR and MFR. In other words, all the connections of the columns to the foundation and the beams to the columns are modeled in the HFR models (3-, 9- and 2-story) as in Fig. 3, and all the connections in the MFR models are designed as in Fig. 4. The differences between these structures are in the floor plans, the number and the height of the stories and finally the locations where the rocking shear walls are placed. The walls are positioned in a specific place (Fig. 6) so that the center of mass and the stiffness center are as close together as possible to prevent torsion. As long as the stiffness center and the center of mass are close to each other, the location of the walls does not significantly affect the performance of the structure. However, if torsion occurs in the structure, the nature of the rocking shear wall, which is the use of sway mechanism, is violated. Therefore, it must be ensured that the walls use only the sway mechanism so that the friction dampers, PT cables and wall-footings work together and therefore can gradually return the structure to its original position and dissipate the earthquake energy imposed to the structures. Fig. 5 shows the elevation view of 3-, 9- and 20-story buildings and the story heights.
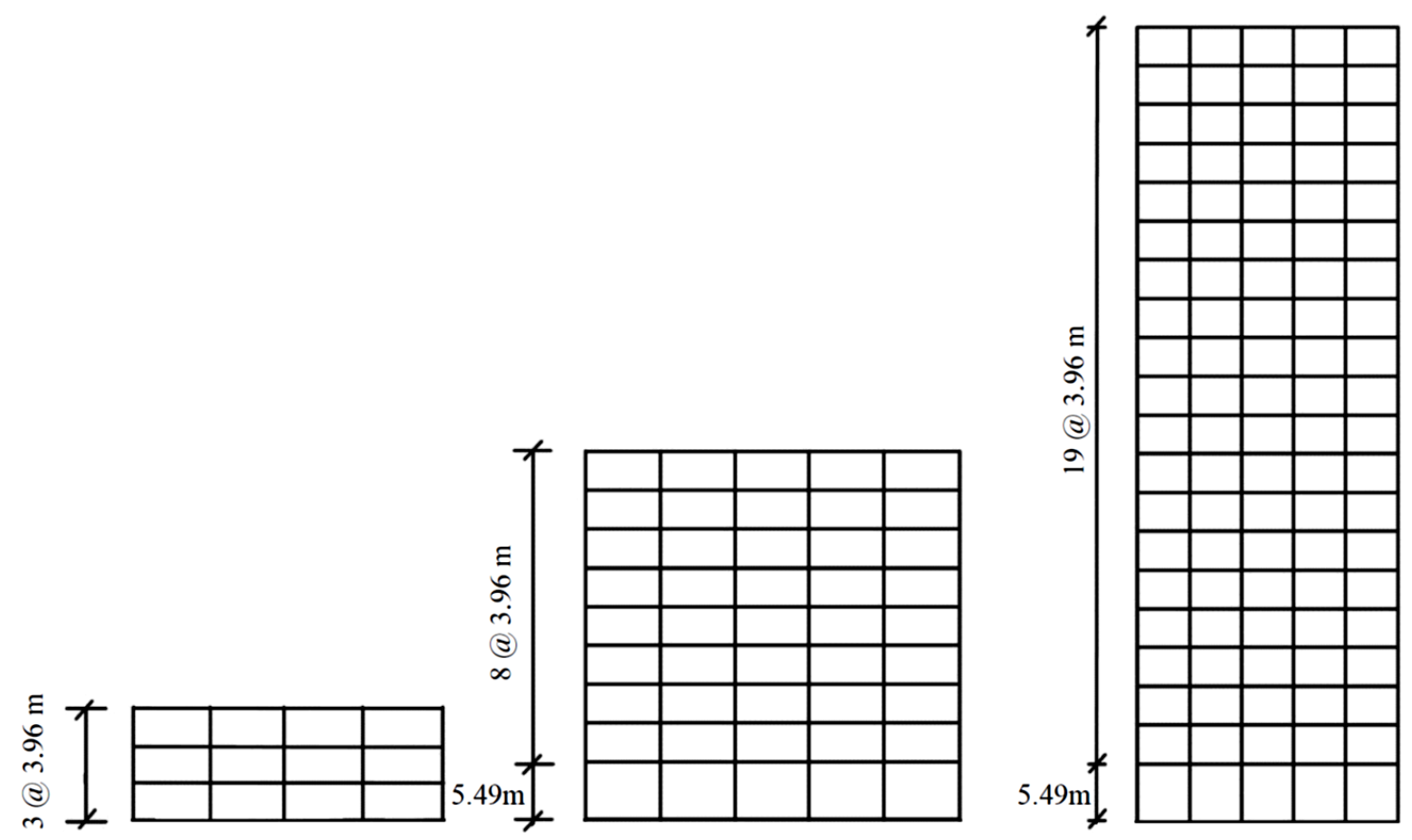

Fig. 5. Elevation view of 3-, 9- and 20-story models

The shear wall-footings were designed to prevent the wall heels from cracking and fracturing in the form of a model and formulas proposed by Chen et al. [14]. The elastic rubber materials and the bulk modulus, tensile strength, shear strength, and Young's modulus were defined according to the Burtscher and Dorfmann models [10] as 2500, $13.5,2.2$, and $6.6 \mathrm{MPa}\left(25493,137.666\right.$ and $\left.67.301 \mathrm{~kg} / \mathrm{cm}^{2}\right)$, respectively. Table 2 shows the dimensions proposed for the walls and footings in each model. 
Table 2. Walls and wall-footing specifications

\begin{tabular}{|c|c|c|c|}
\hline Specifications/Model & 3-Story & 9-Story & 20-Story \\
\hline Wall dimensions $($ length $\times$ depth $\times$ height; $\mathrm{cm})$ & $412 \times 25 \times 1188$ & $412 \times 40 \times 3718$ & $275 \times 80 \times 8077$ \\
\hline Footing dimension $($ length $\times$ depth $\times$ height; $\mathrm{cm})$ & $30 \times 25 \times 50$ & $40 \times 40 \times 50$ & $50 \times 80 \times 50$ \\
\hline Footing cross-section $\left(\mathrm{cm}^{2}\right)$ & $30 \times 25$ & $40 \times 40$ & $50 \times 80$ \\
\hline Height of all rubber layers $(\mathrm{cm})$ & 45 & 45 & 45 \\
\hline Height of a single rubber layer $(\mathrm{cm})$ & 0.6 & 0.6 & 0.9 \\
\hline Modification factor $\mathrm{K}($ dimensionless $)$ & 0.8 & 0.8 & 0.8 \\
\hline
\end{tabular}

In order to design the elastic wall-footings, it was necessary to consider the shape and modification factors of the elastic rubber material. According to report 248 of the National Cooperative Highway Research Program [20], the shape factor of the rectangular bearings was:

$$
S_{1}^{2}=\frac{L W}{2 t(L+W)}
$$

in which $S_{1}, L, W$, and $t$ are the shape factor, length, depth, and height of a single rubber layer, respectively.

To calculate the equivalent elasticity modulus for the elastic wall-footings, the following equations from Chen et al. [14] were used as:

$$
\begin{aligned}
& E_{a p}=E_{0}\left(1+2 \mathrm{k} S_{1}^{2}\right) \\
& E_{c}=\frac{E_{a p} E_{\infty}}{E_{a p}+E_{\infty}} \\
& E_{r b}=\frac{E_{c} A_{r b} h}{T_{r} A_{m}}
\end{aligned}
$$

where $A_{r b}$ is the rubber layer cross-section, $T_{r}$ is the total height of the rubber layers, $E_{r b}$ is the final equivalent elasticity modulus calculated from the rubber footing, $E_{c}$ is the elasticity modulus calculated from the rubber materials considering the shape factor, $h$ is the total height of the wall-footings, $A_{m}$ is the rubber cross-section used in software modeling (equal to $A_{r b}$ in this study), $E_{\infty}$ is the bulk modulus of the rubber materials, and $E_{0}$ is the elasticity modulus of the rubber material.

Kelly [21] presented the following equations to obtain the vertical and horizontal stiffness of the wall-footings as:

$$
\begin{aligned}
& K_{h . r b}=\frac{G \cdot A_{r b}}{T_{r}} \\
& K_{v . r b}=\frac{E_{r b} \cdot A_{r b}}{T_{r}}
\end{aligned}
$$

where $K_{h . r b}$ is the horizontal stiffness of the wall-footings, $K_{v \cdot r b}$ is the vertical stiffness of the wall-footings and $G$ is the shear modulus of the rubber material used in the wall-footings. Table 3 shows the values of both $K_{h . r b}$ and $K_{v . r b}$ considering the rubber material properties and using Eqs. (1) to (6).

Fig. 6. shows the schematic plan view of each model using the proposed system. 
Table 3. Calculations to determine wall-footings properties

\begin{tabular}{|c|c|c|c|}
\hline Specifications/model & 3-story & 9-story & 20-story \\
\hline $\mathbf{S}_{\mathbf{1}}$ & 10.00 & 16.67 & 17.09 \\
\hline $\mathbf{E}_{\mathbf{a p}}\left(\mathbf{k g} / \mathbf{c m}^{\mathbf{2}}\right)$ & 10835 & 29978 & 31532 \\
\hline $\mathbf{E}_{\mathbf{c}}\left(\mathbf{k g} / \mathbf{c m}^{\mathbf{2}}\right)$ & 7603 & 13777 & 14096 \\
\hline $\left.\mathbf{E}_{\mathbf{r b}} \mathbf{( k g} / \mathbf{c m}^{\mathbf{2}}\right)$ & 8448 & 150370 & 15662 \\
\hline $\left.\mathbf{K}_{\mathbf{v . r b}} \mathbf{( k g} / \mathbf{c m}\right)$ & 112644 & 544278 & 1415557 \\
\hline $\left.\mathbf{K}_{\mathbf{h . r b}} \mathbf{( k g} / \mathbf{c m}\right)$ & 299 & 797 & 2492 \\
\hline
\end{tabular}
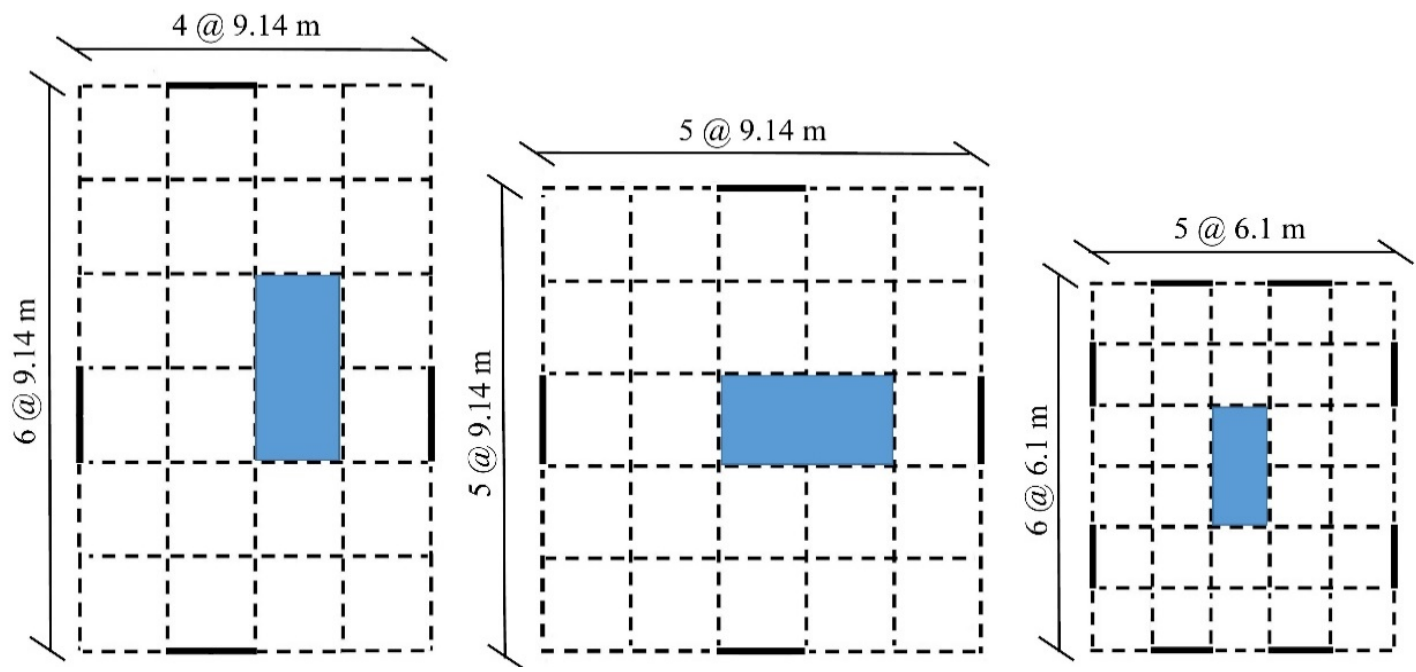

Fig. 6. Floor plans showing locations of proposed hybrid rocking wall attached to the moment and hinged frames.

\subsection{Designing models}

For the addition of the hybrid rocking shear wall, changes were made to the frames connected to the walls. In the first model, the joint connections in the frames were assumed to be hinged, making the rocking shear wall the only lateral bearing system. In the second model, they were assumed to be fixed as conventional moment frames, which resulted in two separate lateral bearing systems working together. The walls were connected to the frames through link beams which were released at both ends. In this model, AISC 360-10 [22] and the Iranian Seismic Code [23] were used to determine the beam and column sections. The characteristics of the structures were selected to be within the scope of conventional building frames. To facilitate the identification of structures and avoid duplication of their characteristics, the structures were denoted as follows:

- 3-story moment frame + rocking shear wall: 3-MFR

- 3-story hinged frame + rocking shear wall: 3-HFR

- 9-story moment frame + rocking shear wall: 9-MFR

- 9-story hinged frame + rocking shear wall: 9-HFR

- 20-story moment frame + rocking shear wall: 20-MFR

- 20-story hinged frame + rocking shear wall: 20 -HFR 
The dynamic characteristics of the structures and the equivalent static coefficients are summarized in Table 4. Table 5, Table 6, and Table 7 show the beam and column sections designed in this study.

Table 4. Dynamic characteristics of the designed models and their equivalent static coefficients

\begin{tabular}{|c|c|c|c|c|c|c|}
\hline \multirow[b]{2}{*}{ Modes } & \multicolumn{3}{|c|}{ HFR models } & \multicolumn{3}{|c|}{ MFR models } \\
\hline & $\begin{array}{l}\text { Frequency } \\
(\mathrm{Hz})\end{array}$ & $\begin{array}{l}\text { fundamental } \\
\text { period }(\mathrm{s})\end{array}$ & $\begin{array}{c}\text { mass participation } \\
\text { ratio }(\%)\end{array}$ & $\begin{array}{l}\text { Frequency } \\
(\mathrm{Hz})\end{array}$ & $\begin{array}{l}\text { fundamental } \\
\text { period (s) }\end{array}$ & $\begin{array}{c}\text { mass participation } \\
\text { ratio }(\%)\end{array}$ \\
\hline \multicolumn{7}{|c|}{ Los Angeles 3-story - Height: $11.88 \mathrm{~m}-$ Equivalent Static $\mathrm{C}=0.1750$} \\
\hline first & 1.53 & 0.65 & 85 & 1.61 & 0.62 & 85 \\
\hline second & 9.09 & 0.11 & 13 & 10.00 & 0.10 & 13 \\
\hline third & 21.27 & 0.047 & 1.5 & 21.74 & 0.046 & 1.6 \\
\hline \multicolumn{7}{|c|}{ Los Angeles 9-story - Height: $37.18 \mathrm{~m}$ - Equivalent Static $\mathrm{C}=0.1012$} \\
\hline first & 0.85 & 1.77 & 80 & 0.59 & 1.69 & 79 \\
\hline second & 1.96 & 0.51 & 13 & 2.08 & 0.48 & 13 \\
\hline third & 5.00 & 0.20 & 4 & 5.26 & 0.19 & 4.3 \\
\hline \multicolumn{7}{|c|}{ Los Angeles 20-story - Height: $80.77 \mathrm{~m}$ - Equivalent Static C $=0.0643$} \\
\hline first & 0.27 & 3.62 & 74 & 0.30 & 3.38 & 74 \\
\hline second & 0.81 & 1.23 & 13 & 0.85 & 1.17 & 13 \\
\hline third & 1.92 & 0.52 & 5.6 & 1.96 & 0.51 & 5.6 \\
\hline
\end{tabular}

Table 5. Designed beam and column sections for Los Angeles 3-story models

\begin{tabular}{|c|c|c|c|c|c|}
\hline Floor & Link beams & Girders & Internal Columns & External Columns (not corners) & Corner Columns \\
\hline \multicolumn{6}{|c|}{ HFR Models } \\
\hline $1,2,3$ & $\mathrm{~W} 4 \times 13$ & $\mathrm{~W} 10 \times 12$ & W14×61 & $\mathrm{W} 14 \times 43$ & $\mathrm{~W} 14 \times 30$ \\
\hline \multicolumn{6}{|c|}{ MFR Models } \\
\hline 1 & $\mathrm{~W} 4 \times 13$ & $\mathrm{~W} 12 \times 19$ & W14×145 & $\mathrm{W} 14 \times 74$ & $\mathrm{~W} 14 \times 53$ \\
\hline 2,3 & $\mathrm{~W} 4 \times 13$ & $\mathrm{~W} 12 \times 16$ & $\mathrm{~W} 14 \times 145$ & $\mathrm{~W} 14 \times 74$ & $\mathrm{~W} 14 \times 53$ \\
\hline
\end{tabular}

Table 6. Designed beam and column sections for Los Angeles 9-story models

\begin{tabular}{|c|c|c|c|c|c|}
\hline Floor & Link beams & Girders & Internal Columns & External Columns (not corners) & Corner Columns \\
\hline \multicolumn{6}{|c|}{ HFR Models } \\
\hline 1 & $\mathrm{~W} 4 \times 13$ & $\mathrm{~W} 10 \times 12$ & $\mathrm{~W} 14 \times 145$ & $\mathrm{~W} 14 \times 90$ & W14×61 \\
\hline 2,3 & $\mathrm{~W} 4 \times 13$ & $\mathrm{~W} 10 \times 12$ & W14×109 & W14×68 & $\mathrm{W} 14 \times 43$ \\
\hline 4,5 & $\mathrm{~W} 4 \times 13$ & $\mathrm{~W} 10 \times 12$ & $\mathrm{~W} 14 \times 90$ & W14×61 & $\mathrm{W} 14 \times 38$ \\
\hline 6,7 & $\mathrm{~W} 4 \times 13$ & $\mathrm{~W} 10 \times 12$ & $\mathrm{~W} 14 \times 68$ & W14×43 & $\mathrm{W} 14 \times 30$ \\
\hline 8,9 & $\mathrm{~W} 4 \times 13$ & $\mathrm{~W} 10 \times 12$ & $\mathrm{~W} 14 \times 43$ & $\mathrm{~W} 14 \times 30$ & $\mathrm{~W} 14 \times 26$ \\
\hline \multicolumn{6}{|c|}{ MFR Models } \\
\hline 1 & $\mathrm{~W} 4 \times 13$ & $\mathrm{~W} 12 \times 22$ & $\mathrm{~W} 14 \times 455$ & $\mathrm{~W} 14 \times 233$ & W14×109 \\
\hline 2,3 & $\mathrm{~W} 4 \times 13$ & $\mathrm{~W} 12 \times 22$ & $\mathrm{~W} 14 \times 211$ & $\mathrm{~W} 14 \times 120$ & $\mathrm{~W} 14 \times 68$ \\
\hline 4,5 & $\mathrm{~W} 4 \times 13$ & $\mathrm{~W} 12 \times 22$ & $\mathrm{~W} 14 \times 159$ & $\mathrm{~W} 14 \times 90$ & W14×61 \\
\hline 6,7 & $\mathrm{~W} 4 \times 13$ & $\mathrm{~W} 12 \times 26$ & $\mathrm{~W} 14 \times 109$ & W14×68 & W14×43 \\
\hline 8 & $\mathrm{~W} 4 \times 13$ & $\mathrm{~W} 12 \times 19$ & W14×74 & $\mathrm{W} 14 \times 43$ & $\mathrm{~W} 14 \times 30$ \\
\hline 9 & $\mathrm{~W} 4 \times 13$ & $\mathrm{~W} 12 \times 16$ & W14×74 & W14×43 & $\mathrm{W} 14 \times 30$ \\
\hline
\end{tabular}


Table 7. Designed beam and column sections for Los Angeles 20-story models

\begin{tabular}{|c|c|c|c|c|c|}
\hline Floor & Link beams & Girders & Internal Columns & External Columns (not corners) & Corner Columns \\
\hline \multicolumn{6}{|c|}{ HFR Models } \\
\hline 1 & $\mathrm{~W} 4 \times 13$ & $\mathrm{~W} 10 \times 12$ & $\mathrm{~W} 14 \times 145$ & $\mathrm{~W} 14 \times 90$ & $\mathrm{~W} 14 \times 61$ \\
\hline 2,3 & $\mathrm{~W} 4 \times 13$ & $\mathrm{~W} 10 \times 12$ & $\mathrm{~W} 14 \times 120$ & $\mathrm{~W} 14 \times 74$ & $\mathrm{~W} 14 \times 48$ \\
\hline 4,5 & $\mathrm{~W} 4 \times 13$ & $\mathrm{~W} 10 \times 12$ & $\mathrm{~W} 14 \times 109$ & $\mathrm{~W} 14 \times 68$ & $\mathrm{~W} 14 \times 43$ \\
\hline 6,7 & $\mathrm{~W} 4 \times 13$ & $\mathrm{~W} 10 \times 12$ & $\mathrm{~W} 14 \times 99$ & $\mathrm{~W} 14 \times 61$ & $\mathrm{~W} 14 \times 43$ \\
\hline 8,9 & $\mathrm{~W} 4 \times 13$ & $\mathrm{~W} 10 \times 12$ & $\mathrm{~W} 14 \times 90$ & $\mathrm{~W} 14 \times 53$ & $\mathrm{~W} 14 \times 38$ \\
\hline 10,11 & $\mathrm{~W} 4 \times 13$ & $\mathrm{~W} 10 \times 12$ & $\mathrm{~W} 14 \times 82$ & $\mathrm{~W} 14 \times 48$ & $\mathrm{~W} 14 \times 34$ \\
\hline 12,13 & $\mathrm{~W} 4 \times 13$ & $\mathrm{~W} 10 \times 12$ & W14×68 & $\mathrm{W} 14 \times 43$ & $\mathrm{~W} 14 \times 30$ \\
\hline 14 & $\mathrm{~W} 4 \times 13$ & $\mathrm{~W} 10 \times 12$ & $\mathrm{~W} 14 \times 61$ & $\mathrm{~W} 14 \times 38$ & $\mathrm{~W} 14 \times 30$ \\
\hline 15 & $\mathrm{~W} 4 \times 13$ & $\mathrm{~W} 10 \times 12$ & $\mathrm{~W} 14 \times 53$ & $\mathrm{~W} 14 \times 38$ & $\mathrm{~W} 14 \times 30$ \\
\hline 16 & $\mathrm{~W} 4 \times 13$ & $\mathrm{~W} 10 \times 12$ & $\mathrm{~W} 14 \times 53$ & $\mathrm{~W} 14 \times 30$ & $\mathrm{~W} 14 \times 26$ \\
\hline 17 & $\mathrm{~W} 4 \times 13$ & $\mathrm{~W} 10 \times 12$ & $\mathrm{~W} 14 \times 43$ & $\mathrm{~W} 14 \times 30$ & W14×26 \\
\hline 18 & $\mathrm{~W} 4 \times 13$ & $\mathrm{~W} 10 \times 12$ & $\mathrm{~W} 14 \times 43$ & $\mathrm{~W} 14 \times 30$ & $\mathrm{~W} 14 \times 22$ \\
\hline 19,20 & $\mathrm{~W} 4 \times 13$ & $\mathrm{~W} 10 \times 12$ & $\mathrm{~W} 14 \times 30$ & $\mathrm{~W} 14 \times 26$ & W14×22 \\
\hline \multicolumn{6}{|c|}{ MFR Models } \\
\hline 1 & $\mathrm{~W} 4 \times 13$ & $\mathrm{~W} 12 \times 22$ & $\mathrm{~W} 14 \times 500$ & $\mathrm{~W} 14 \times 283$ & $\mathrm{~W} 14 \times 176$ \\
\hline 2 & $\mathrm{~W} 4 \times 13$ & $\mathrm{~W} 12 \times 22$ & $\mathrm{~W} 14 \times 283$ & $\mathrm{~W} 14 \times 159$ & $\mathrm{~W} 14 \times 99$ \\
\hline 3 & $\mathrm{~W} 4 \times 13$ & $\mathrm{~W} 12 \times 26$ & $\mathrm{~W} 14 \times 283$ & $\mathrm{~W} 14 \times 159$ & $\mathrm{~W} 14 \times 99$ \\
\hline 4 & $\mathrm{~W} 4 \times 13$ & $\mathrm{~W} 12 \times 30$ & $\mathrm{~W} 14 \times 283$ & $\mathrm{~W} 14 \times 159$ & $\mathrm{~W} 14 \times 99$ \\
\hline 5 & $\mathrm{~W} 4 \times 13$ & $\mathrm{~W} 12 \times 35$ & $\mathrm{~W} 14 \times 283$ & $\mathrm{~W} 14 \times 159$ & $\mathrm{~W} 14 \times 99$ \\
\hline 6,7 & $\mathrm{~W} 4 \times 13$ & $\mathrm{~W} 12 \times 35$ & $\mathrm{~W} 14 \times 283$ & $\mathrm{~W} 14 \times 145$ & $\mathrm{~W} 14 \times 90$ \\
\hline 8,9 & $\mathrm{~W} 4 \times 13$ & $\mathrm{~W} 12 \times 35$ & $\mathrm{~W} 14 \times 211$ & $\mathrm{~W} 14 \times 312$ & $\mathrm{~W} 14 \times 90$ \\
\hline 10 & $\mathrm{~W} 4 \times 13$ & $\mathrm{~W} 12 \times 35$ & $\mathrm{~W} 14 \times 193$ & $\mathrm{~W} 14 \times 109$ & $\mathrm{~W} 14 \times 90$ \\
\hline 11 & $\mathrm{~W} 4 \times 13$ & $\mathrm{~W} 12 \times 30$ & $\mathrm{~W} 14 \times 193$ & $\mathrm{~W} 14 \times 109$ & $\mathrm{~W} 14 \times 90$ \\
\hline 12 & $\mathrm{~W} 4 \times 13$ & $\mathrm{~W} 12 \times 30$ & $\mathrm{~W} 14 \times 145$ & $\mathrm{~W} 14 \times 90$ & $\mathrm{~W} 14 \times 68$ \\
\hline 13 & $\mathrm{~W} 4 \times 13$ & $\mathrm{~W} 12 \times 26$ & $\mathrm{~W} 14 \times 145$ & $\mathrm{~W} 14 \times 90$ & $\mathrm{~W} 14 \times 68$ \\
\hline 14,15 & $\mathrm{~W} 4 \times 13$ & $\mathrm{~W} 12 \times 22$ & $\mathrm{~W} 14 \times 120$ & $\mathrm{~W} 14 \times 82$ & $\mathrm{~W} 14 \times 61$ \\
\hline 16 & $\mathrm{~W} 4 \times 13$ & $\mathrm{~W} 12 \times 22$ & $\mathrm{~W} 14 \times 90$ & $\mathrm{~W} 14 \times 61$ & $\mathrm{~W} 14 \times 48$ \\
\hline 17 & $\mathrm{~W} 4 \times 13$ & $\mathrm{~W} 12 \times 19$ & $\mathrm{~W} 14 \times 90$ & $\mathrm{~W} 14 \times 61$ & $\mathrm{~W} 14 \times 48$ \\
\hline 18 & $\mathrm{~W} 4 \times 13$ & $\mathrm{~W} 12 \times 16$ & $\mathrm{~W} 14 \times 61$ & $\mathrm{~W} 14 \times 43$ & $\mathrm{~W} 14 \times 38$ \\
\hline 19 & $\mathrm{~W} 4 \times 13$ & $\mathrm{~W} 12 \times 16$ & $\mathrm{~W} 14 \times 61$ & $\mathrm{~W} 14 \times 43$ & $\mathrm{~W} 14 \times 30$ \\
\hline 20 & $\mathrm{~W} 4 \times 13$ & $\mathrm{~W} 12 \times 14$ & $\mathrm{~W} 14 \times 43$ & $\mathrm{~W} 14 \times 30$ & $\mathrm{~W} 14 \times 30$ \\
\hline
\end{tabular}




\section{Ground motion records}

The ground motion records used in the time-history analysis were provided and modified by the SAC joint venture. These SAC-modified ground motion records were 14 pairs of near-field records and were applied to the structure at two levels of hazard (50\% in 50 years; $10 \%$ in 50 years). Table 8 lists the ground motions and their characteristics.

Table 8. Characteristics of SAC modified ground motion records for time-history analysis [19]

\begin{tabular}{|c|c|c|c|c|c|}
\hline \multicolumn{5}{|c|}{ Los Angeles 10-in-50 } \\
\hline EQ code & Description & Magnitude & Distance (km) & Scale Factor & PGA (g) \\
\hline la01 & fn Imperial Valley, 1940, El Centro & 6.9 & 10.0 & 2.01 & 0.46 \\
\hline la02 & fp Imperial Valley, 1940, El Centro & 6.9 & 10.0 & 2.01 & 0.68 \\
\hline la03 & fn Imperial Valley, 1979, \#05 & 6.5 & 4.1 & 1.01 & 0.39 \\
\hline la04 & fp Imperial Valley, 1979, \#05 & 6.5 & 4.1 & 1.01 & 0.49 \\
\hline la05 & fn Imperial Valley, 1979, \#06 & 6.5 & 1.2 & 0.84 & 0.30 \\
\hline la06 & fp Imperial Valley, 1979, \#06 & 6.5 & 1.2 & 0.84 & 0.23 \\
\hline la11 & fn Loma Prieta, 1989, Gilroy & 7.0 & 12.0 & 1.79 & 0.67 \\
\hline la12 & fp Loma Prieta, 1989, Gilroy & 7.0 & 12.0 & 1.79 & 0.97 \\
\hline la13 & fn Northridge, 1994, Newhall & 6.7 & 6.7 & 1.03 & 0.68 \\
\hline la14 & fp Northridge, 1994, Newhall & 6.7 & 6.7 & 1.03 & 0.66 \\
\hline la15 & fn Northridge, 1994, Rinaldi RS & 6.7 & 7.5 & 0.79 & 0.53 \\
\hline la16 & fp Northridge, 1994, Rinaldi RS & 6.7 & 7.5 & 0.79 & 0.58 \\
\hline la17 & fn Northridge, 1994, Sylmar & 6.7 & 6.4 & 0.99 & 0.57 \\
\hline la18 & fp Northridge, 1994, Sylmar & 6.7 & 6.4 & 0.99 & 0.82 \\
\hline la19 & fn North Palm Springs, 1986 & 6.0 & 6.7 & 2.97 & 1.02 \\
\hline la20 & fp North Palm Springs, 1986 & 6.0 & 6.7 & 2.97 & 0.99 \\
\hline & & & & \\
\hline
\end{tabular}

Los Angeles 50-in-50

\begin{tabular}{|c|c|c|c|c|c|}
\hline la41 & fn Coyote Lake, 1979 & 5.7 & 8.8 & 2.28 & 0.59 \\
\hline la42 & fp Coyote Lake, 1979 & 5.7 & 8.8 & 2.28 & 0.33 \\
\hline la43 & fn Imperial Valley 1979 & 6.5 & 1.2 & 0.40 & 0.14 \\
\hline la44 & fp Imperial Valley 1979 & 6.5 & 1.2 & 0.40 & 0.11 \\
\hline la51 & fn Parkfield, 1966, Cholame 5W & 6.1 & 3.7 & 1.81 & 0.78 \\
\hline la52 & fp Parkfield, 1966, Cholame 5W & 6.1 & 3.7 & 1.81 & 0.63 \\
\hline la53 & fn Parkfield, 1966, Cholame 8W & 6.1 & 8.0 & 2.92 & 0.69 \\
\hline la54 & fp Parkfield, 1966, Cholame 8W & 6.1 & 8.0 & 2.92 & 0.79 \\
\hline la55 & fn North Palm Springs, 1986 & 6.0 & 9.6 & 2.75 & 0.52 \\
\hline la56 & fp North Palm Springs, 1986 & 6.0 & 9.6 & 2.75 & 0.38 \\
\hline la57 & fn San Fernando, 1971 & 6.5 & 1.0 & 1.30 & 0.25 \\
\hline la58 & fp San Fernando, 1971 & 6.5 & 1.0 & 1.30 & 0.23 \\
\hline
\end{tabular}




\section{Results and discussion}

The results of the nonlinear dynamic time-history analysis of the frames subjected to 14 modified ground motion records were interpreted and compared.

\subsection{Relative displacement (drifts)}

In order to report the inter-story displacement diagrams, the maximum relative displacement experienced by each floor during the earthquake was used (15\%, average and $84 \%$ fractals). Fig. 7 shows the statistical diagram of the relative displacement of 3-HFR and 3-MFR models. It shows that In terms of relative displacement, the 3-HFR models experienced, on average, $14.9 \%$ more relative displacement than the 3-MFR models.

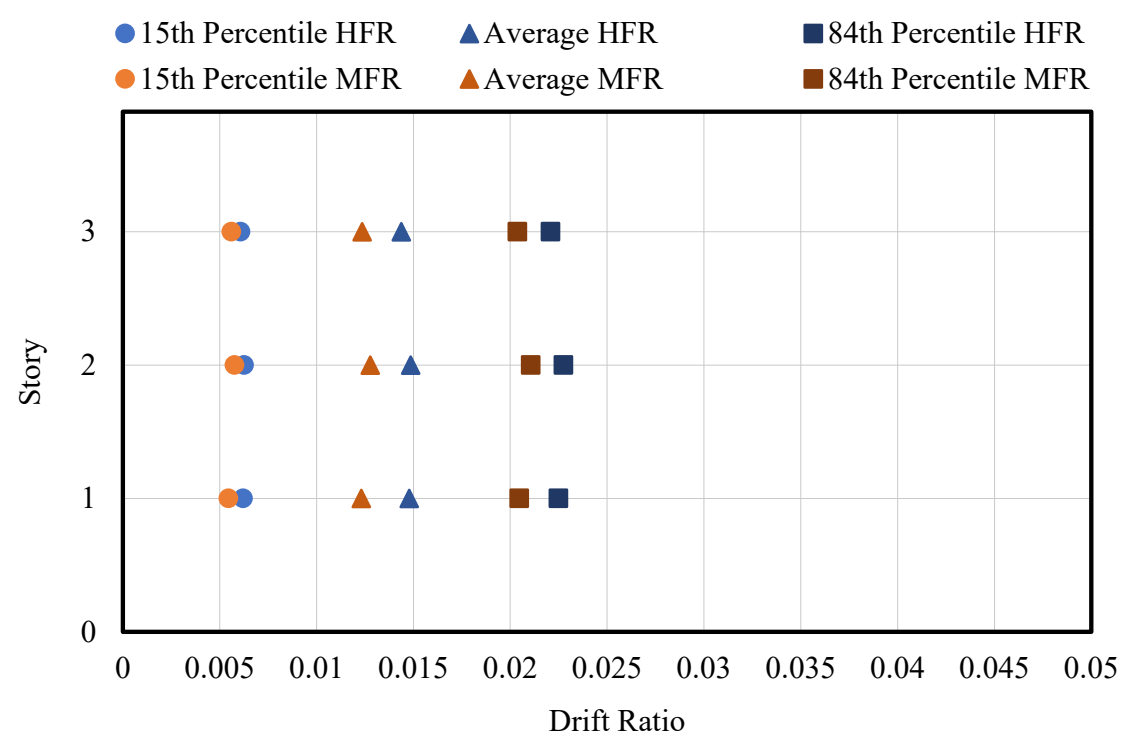

Fig. 7. Relative displacement of 3-HFR and 3-MFR models proposed in this study

Fig. 8(a) and (b) show the statistical diagram of the relative displacement of 3-HFR and 3-MFR models under 50in-50 and 10-in-50 ground motions, respectively. According to the figure, it can be seen that the smallest difference in response between the two models belongs to the Imperial Valley, 1979 (LA43-LA44) earthquake and the largest difference in response belongs to the Northridge, 1994, Rinaldi RS (LA15-LA16) earthquake. It can also be found that in 13 out of 14 earthquakes, the HFR model experienced higher relative displacements than the MFR one. Only in the Northridge, 1994, Newhall (LA13-LA14) earthquake, despite having two lateral load bearing systems, the MFR model experienced more relative displacement than the HFR model. However, the global behavior of the both models at both levels of hazard was the same. 

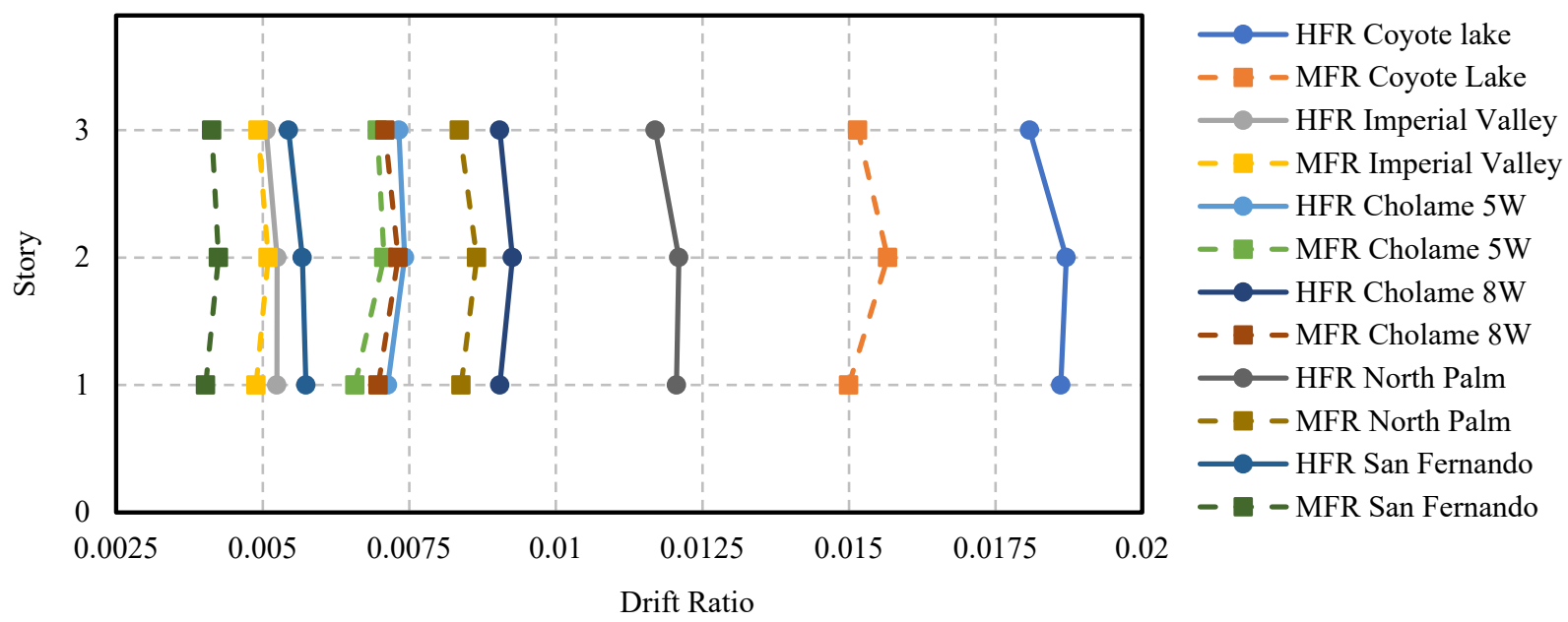

(a)
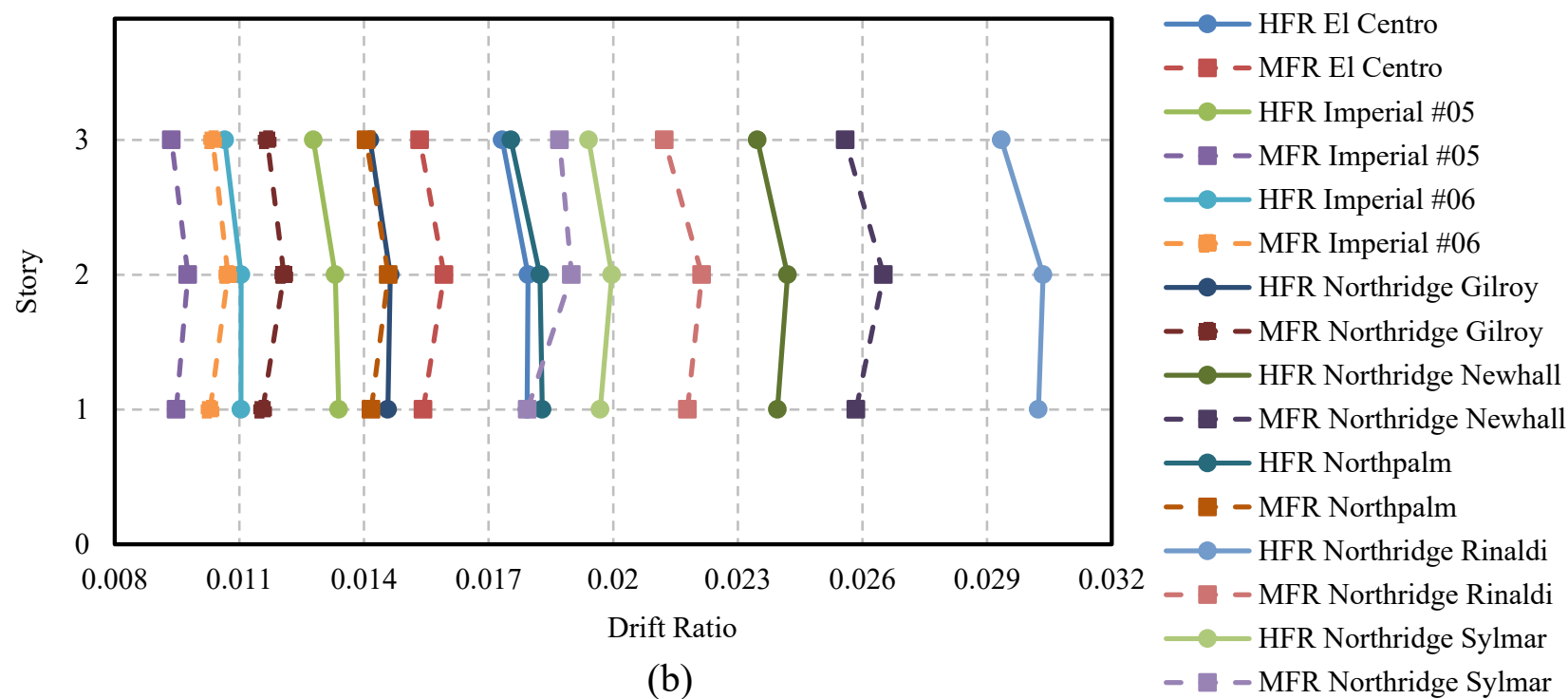

(b)

Fig. 8. Relative displacement of 3-HFR and 3-MFR models under (a) 50-in-50 and (b) 10-in-50 ground motions

Likewise, it can be concluded from this study that both 9-HFR and 9-MFR models showed similar global behaviors at both 50-in-50 and 10-in-50 hazard levels. Models subjected to 50-in-50 earthquakes experienced similar average relative displacements and little difference was observed. This difference was noticeable in the 10-in-50 hazard level, especially for the Imperial Valley earthquakes (LA03-04, 05-06 and 43-44 (see Fig. 11b)). The 9-HFR model experienced, on average, $10.1 \%$ more relative displacement than the 9-MFR model. This difference in relative displacement was further confirmed by the fact that all HFR joints are released (hinged) and hinged connections unlike the 9-MFR joints (fixed), cannot resist lateral loads. The relative displacements of all models were within 5\% of the regulations for moment frames. Fig. 9 shows the statistical diagram of the relative displacement of the 9-HFR and 9MFR models proposed in this study. 


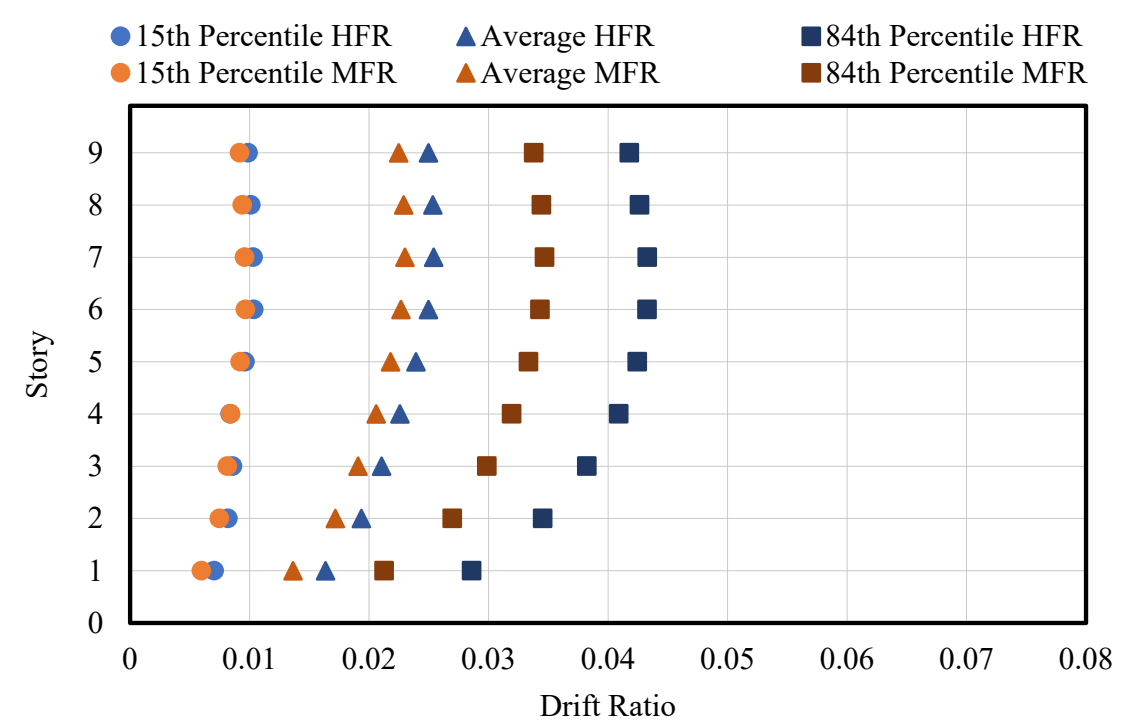

Fig. 9. Relative displacement of 9-HFR and 9-MFR models proposed in this study

Similarly, according to the results obtained from the study, at the 50-in-50 and 10-in-50 hazard levels, the behavior of both the 20-HFR and 20-MFR models was almost the same. However, as can be seen in Fig. 10, the 20-MFR models had, on average, $11.8 \%$ less relative displacement than the 20-HFR models. This difference was most noticeable at 10-in-50 hazard level, especially for the 1940 El Centro (LA01-02) and 1994 Northridge Rinaldi RS (LA15-16) earthquakes. It should also be noted that the behavior of the high-rise 20-story models from the first floor to the middle height (story 10) was both uniform and re-centered. However, the upper floors experienced more relative displacement that was exhibited as slowly drifting away from the center line of the wall.

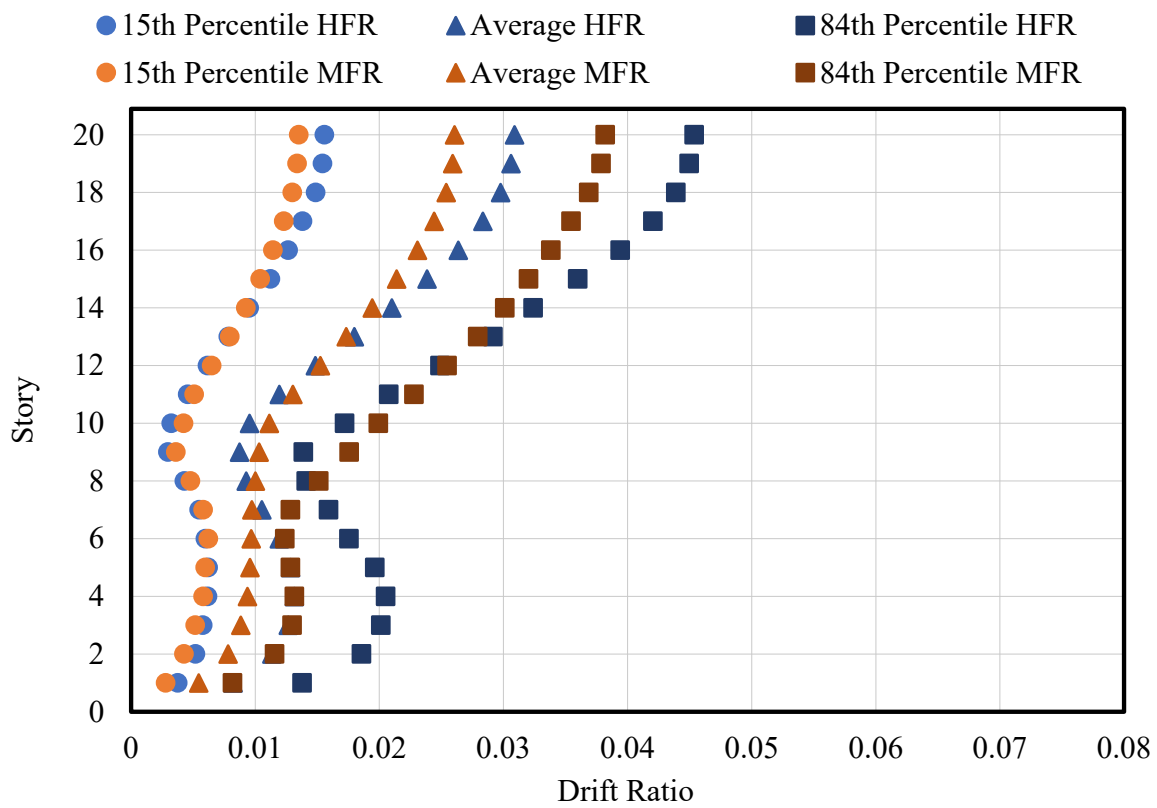

Fig. 10. Relative displacement of $20-\mathrm{HFR}$ and $20-\mathrm{MFR}$ models proposed in this study 
It was also observed in the high-rise models that, at the ends of the columns of the top floor, regardless of the strength or weakness of the section, plastic hinges formed easily. The reason for this was likely the activation and effect of higher modes on the high-rise model. Comparison of the statistical diagrams of all six models indicates that the relative displacement of all 3, 9, and 20 HFR models was higher than the MFR models on average. It can also be seen that the behavior of the structures was similar for both the HFR and MFR models. However, the relative displacement of all models was within $5 \%$ of the regulations.

\subsection{Roof displacement}

Fig. 11 shows that the models with hinged connections in the low-rise 3-story and mid-rise 9-story buildings, on average, experienced higher displacement at the rooftop center of mass. These types of connections made the structure become softer. For a few earthquake records, the displacement of the MFR models was greater than for the models with hinged connections.

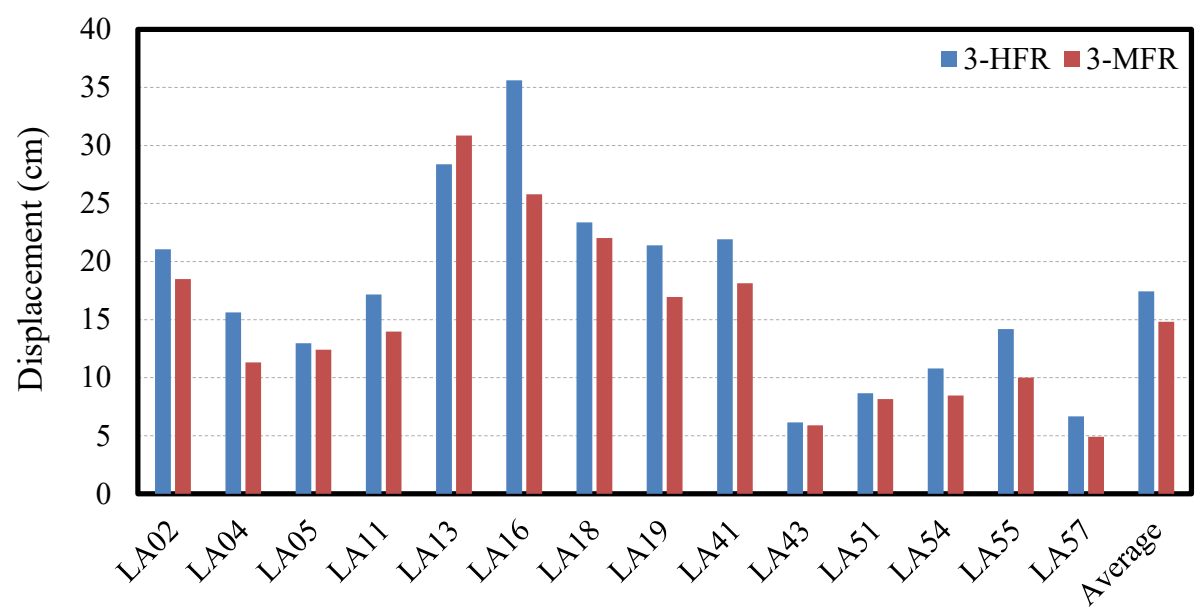

(a)

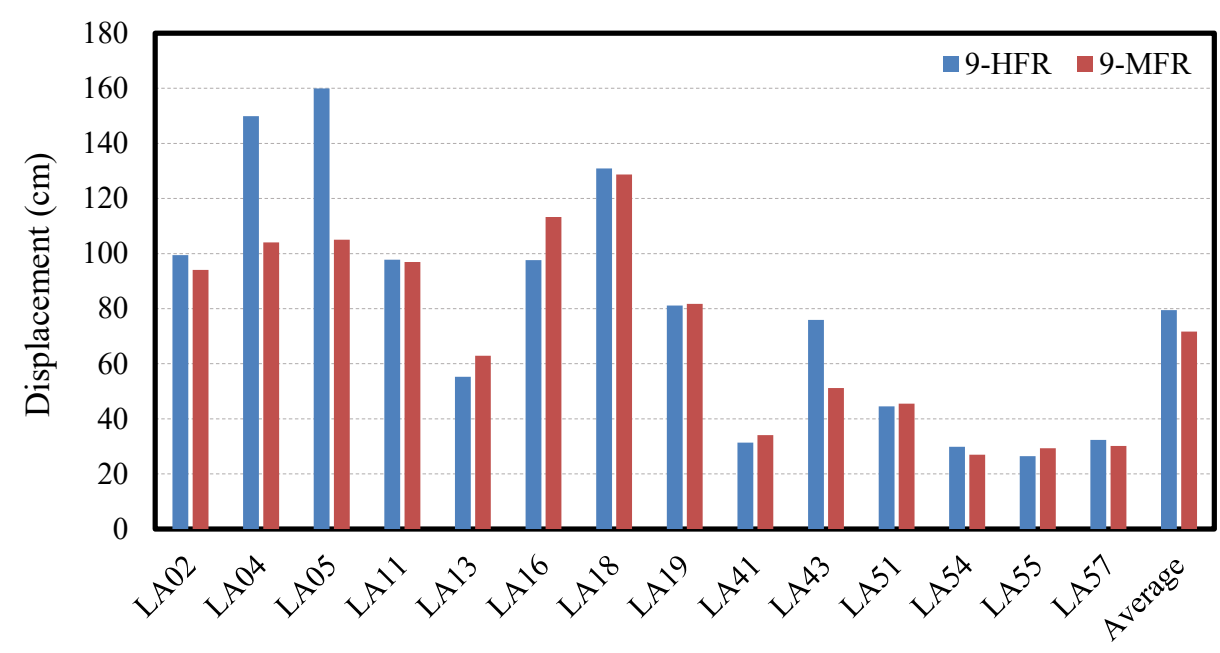

(b)

Fig. 11. Rooftop displacement of 3- and 9-story models for each ground motion record: (a) 3 stories; (b) 9 stories 
In the high-rise models, the displacement of the rooftop center of mass was, on average, greater in the MFR models compared to the HFR models. The results in section 4.1 showed less relative displacement for the MFR models; thus, it can be concluded that MFR models, with more maximum rooftop displacement and less relative displacement than the HFR models, showed more uniform behavior in the high-rise structures (Fig. 12).

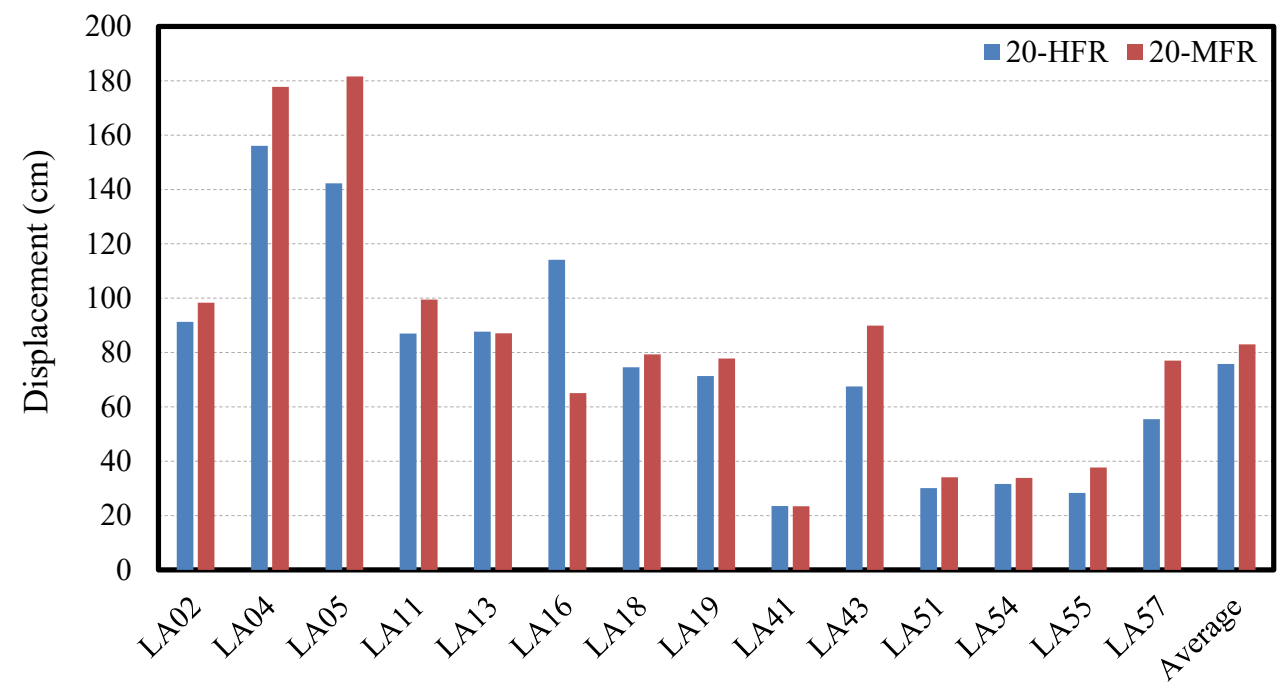

Fig. 12. Rooftop displacement of 20 -story models in each ground motion record

By observing Figs. 11 and 12, it can be seen that in the low-rise model, only in 1 out of 14 earthquakes, the maximum rooftop displacement in the MFR model is more than the HFR. This number reaches 6 out of 14 in the midrise model and finally reaches 12 out of 14 in the high-rise model. This indicates that as the height of the structure increases, the HFR model experiences less maximum rooftop displacement. However, in terms of relative displacement, according to Figs. 7, 9 and 10, it was seen that the MFR models experienced less relative displacement than the HFR models. From these two results, it can be concluded that with increasing the height of the structures, the MFR model shows a more uniform behavior, while in low-rise and mid-rise models, both models exhibit almost the same uniformity.

Also, by comparing Figs. 11 and 12, it can be seen that the 3-story models present the lowest rooftop displacements when subjected to Imperial Valley, \#05 (LA03-04) and Imperial Valley, \#06 (LA05-06) earthquake records in 10-in50 hazard level. On contrary, under the same earthquake records, the 9-story and 20-story models exhibit the highest rooftop displacements. This phenomenon can be explained by extracting the Fourier Amplitude-Frequency diagram (Fig. 13) from the earthquake records and comparing the frequency in which the earthquake power is the highest with the frequency of the three structures (vertically higher points on the curve indicate more earthquake powers). For example, for Imperial Valley, \#06 (LA05) earthquake record, according to Fig. 13, it can be seen how this earthquake record intensified the mid- and high-rise structures, but did not have a significant effect on the low-rise structures. 


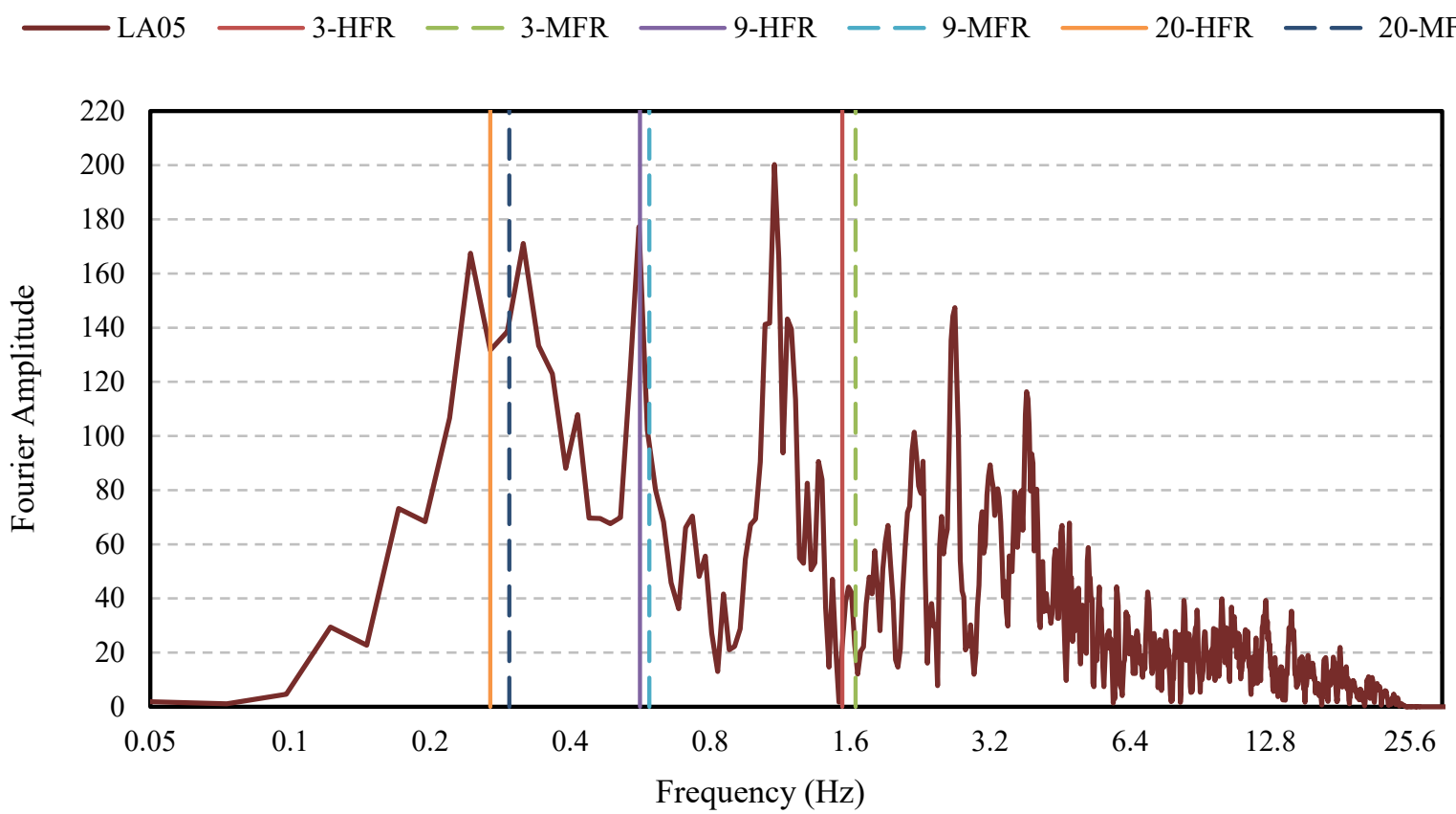

Fig. 13. Effect of frequency content on the low-, mid- and high-rise structures in LA05 earthquake record

In Figs. 14 and 15, the 3- and 9-story HFR models had average rooftop displacement values of 15\% and 9.8\% higher, respectively, than the MFR models; however, the global behavior of both models were similar to each other. It was concluded that the energy dissipating members were able to successfully damp the seismic energy imposed on the structures, allowing them to return to their initial positions after rocking several times. Fig. 16 also reveals that, unlike 3- and 9-story models, in the 20-story models, the MFR models experienced an average roof displacement of $9.6 \%$ greater than that of the HFR models.

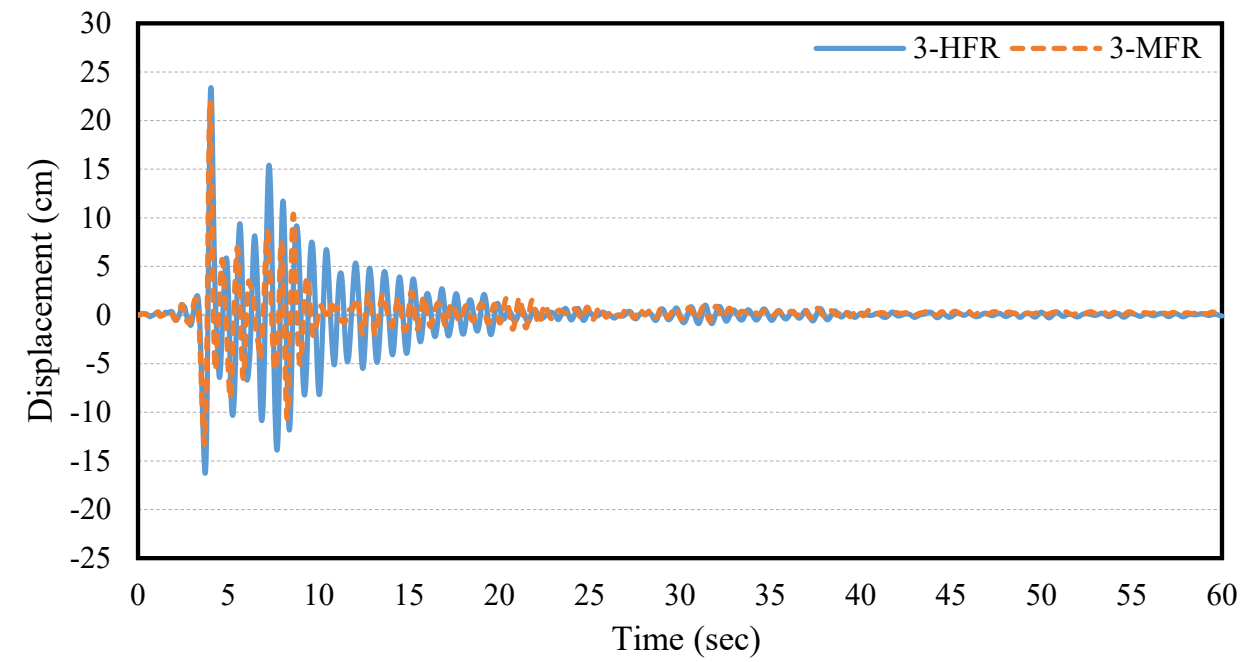

Fig. 14. Rooftop time-history displacement of both 3-story systems subjected to Northridge 1994 Sylmar (LA17-18) ground motion record 


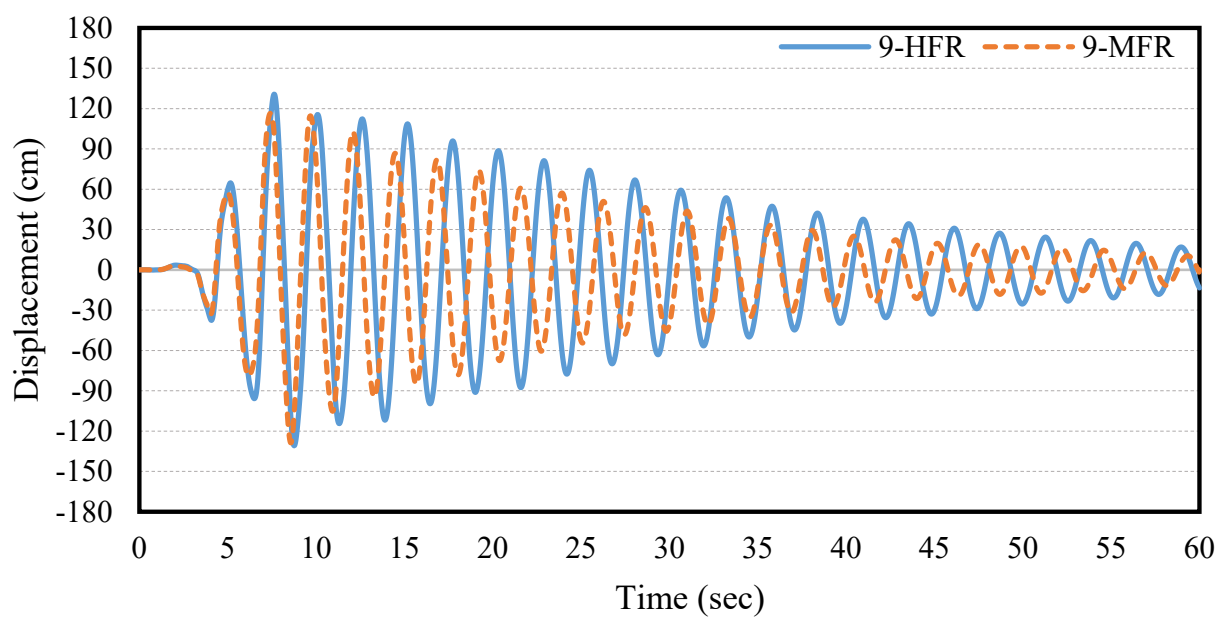

Fig. 15. Rooftop time-history displacement of both 9-story systems subjected to Northridge 1994 Sylmar (LA17-18) ground motion record

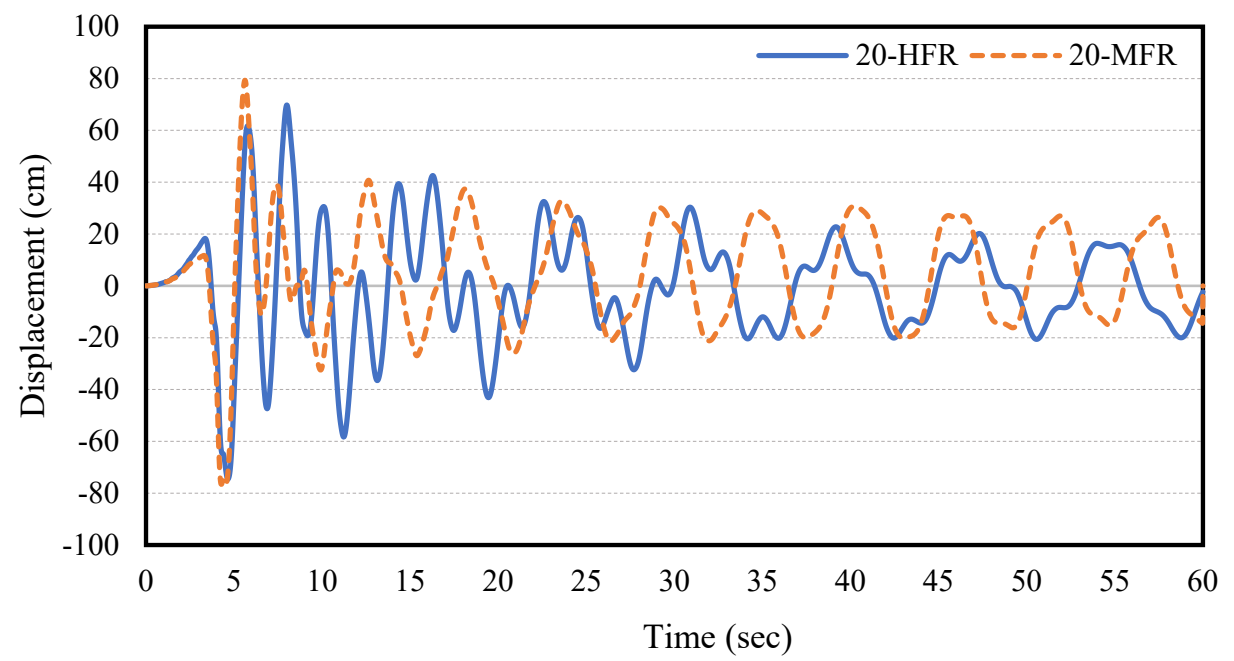

Fig. 16. Rooftop time-history displacement of both 20 -story systems subjected to Northridge 1994 Sylmar (LA17-18) ground motion record

The different time-history plots indicate that, during the earthquake, the combination of modes in the 20-HFR model was more common while 20-MFR model rocked in one mode as shown in Fig. 16. Also it was observed according to the Fig. 13, that the MFR model with a higher frequency, is more likely to undergo more seismic power than the HFR model. These two could be the reason for the decrease in the maximum displacement of the 20-HFR models as compared to the 20-MFR models (Fig. 12 and Fig. 16). It also can be seen that the structures in the highrise models were unable to easily return to their initial positions and kept rocking until they were damped. The high amount of concrete used, the effect of the higher modes, weak energy dissipative devices, and other model characteristics (being a high-rise, dynamic characteristics) could have contributed to this failure. 


\subsection{Material contents}

Fig. 17 shows the amounts of materials used in the two proposed systems. A comparison of all HFR and MFR models with the same concrete contents and wall specifications shows that the amount of steel used in the HFR models decreased sharply compared to MFR models because of the hinged connections.

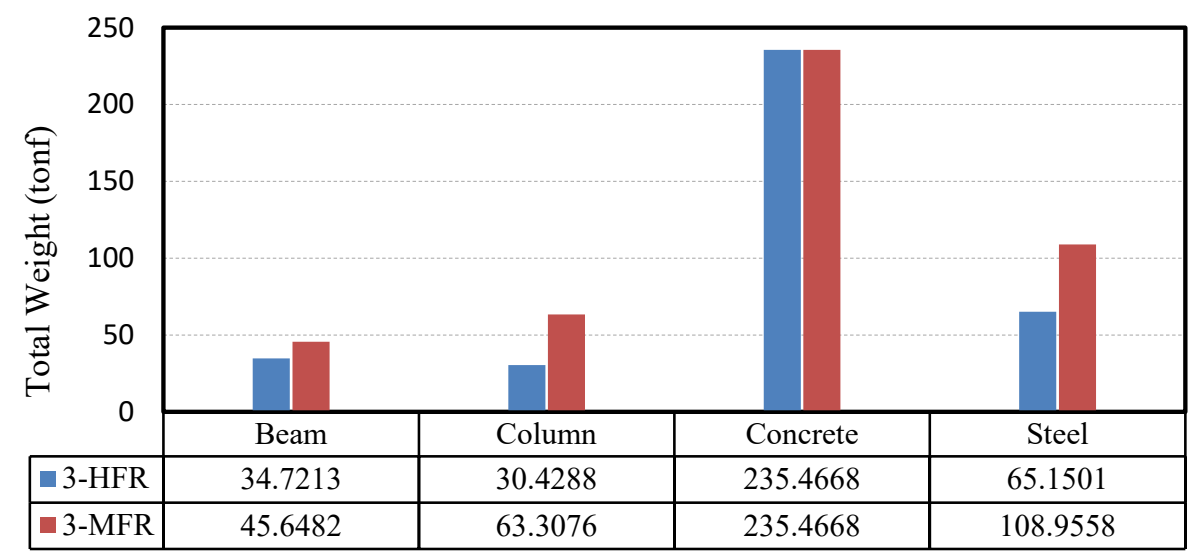

(a)

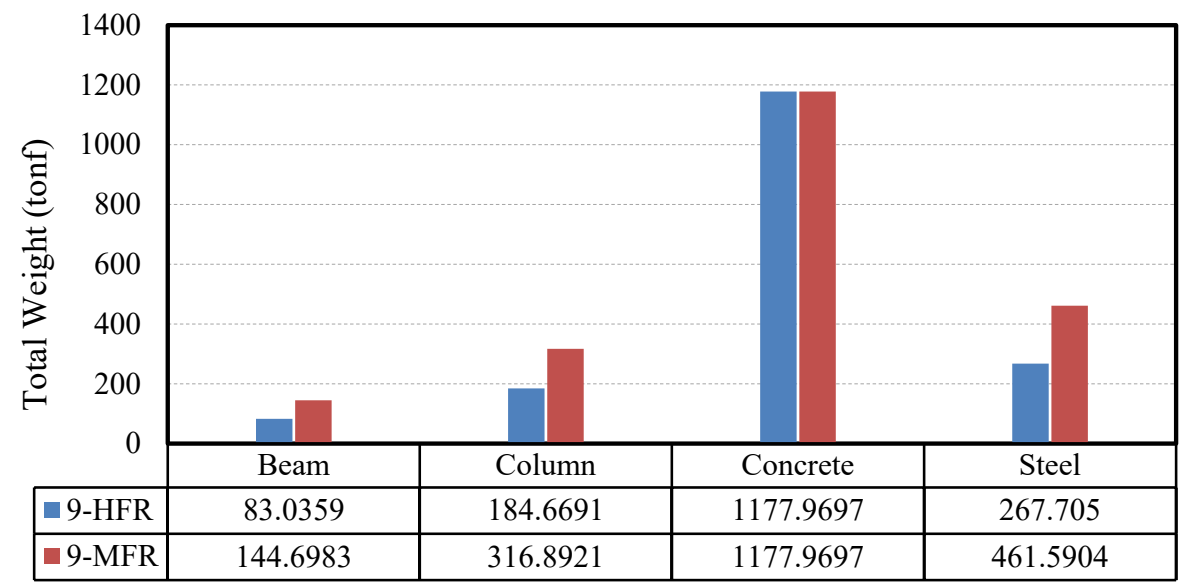

(b)

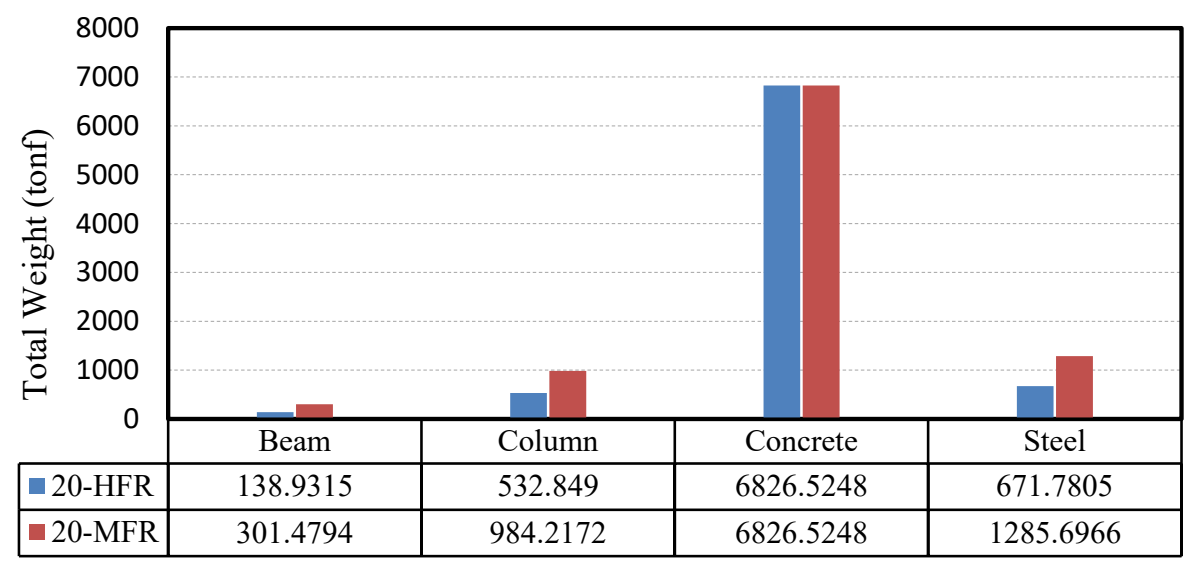

(c)

Fig. 17. Amount of materials used in proposed HFR and MFR models: (a) 3 stories; (b) 9 stories; (c) 20 stories 


\subsection{Base shear}

Fig. 18 shows no significant difference in the base shear of the two models, on average. In the 3- and 20-story structures, the HFR models recorded slightly higher base shear values than the MFR models on average. However, in the 9-story model, the MFR model recorded a higher base-shear than the HFR model, but the difference was not significant. As all of these base shear differences were hardly noticeable on average, they can be ignored.

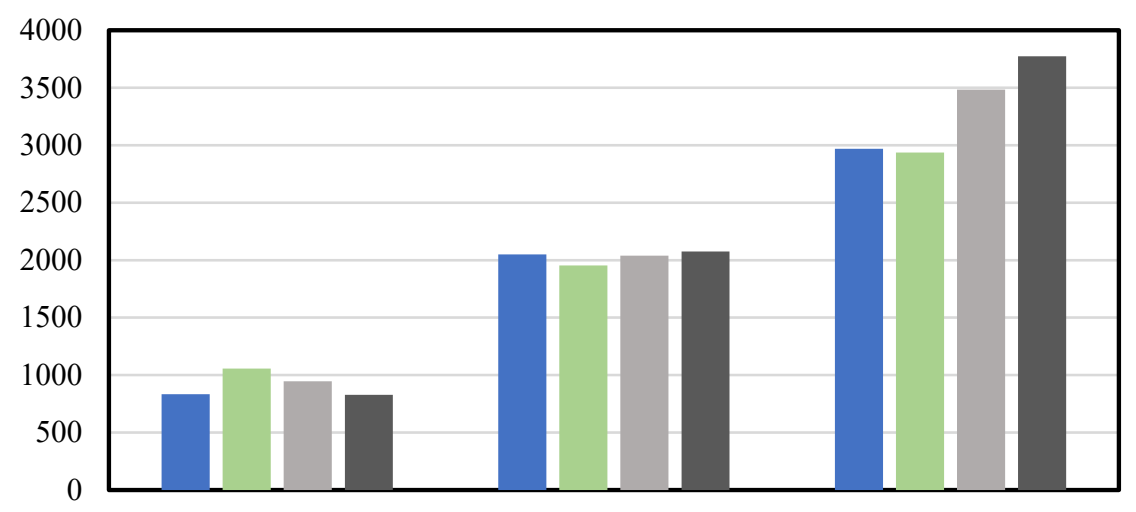

(a)

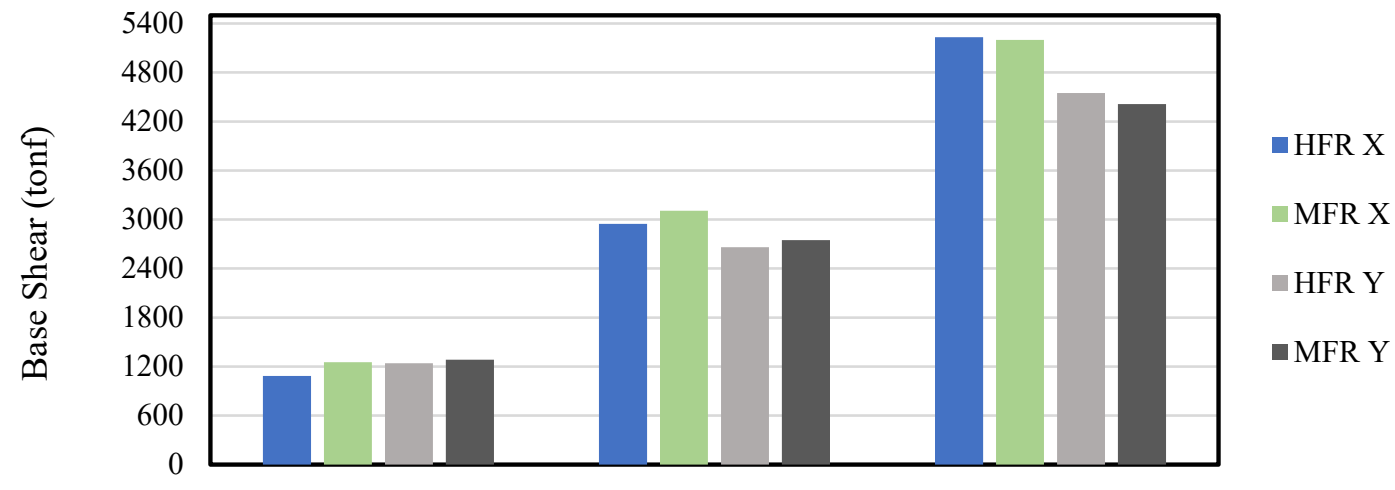

(b)

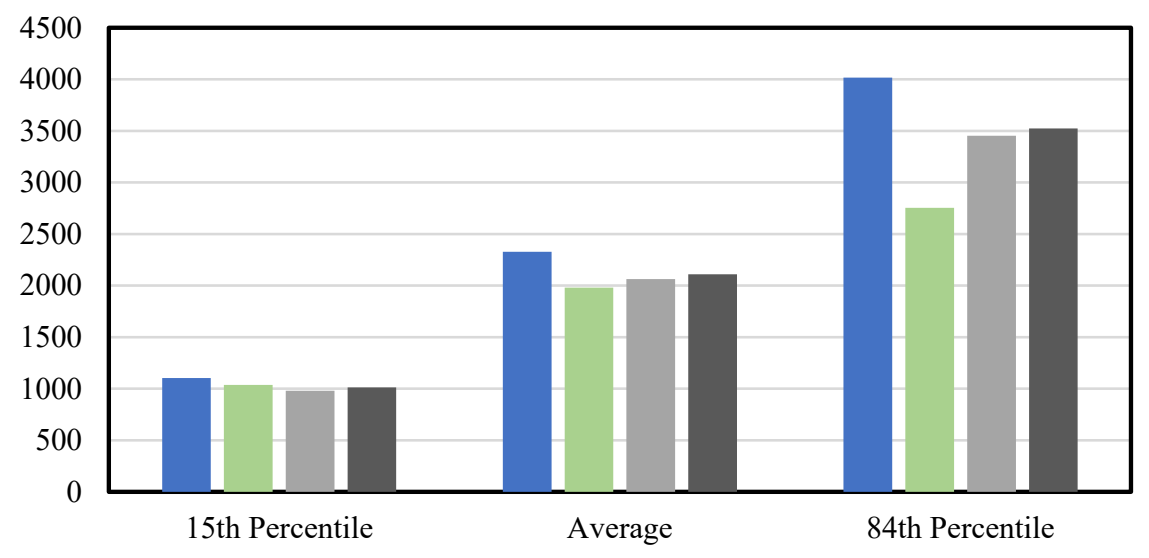

(c)

Fig. 18. Base shear of models for both proposed systems: (a) 3 stories; (b) 9 stories; (c) 20 stories 


\section{Conclusion}

A summary of the results obtained in the present research is as follows:

- After releasing the joints, the fundamental periods of the 3-, 9-, and 20-story HFR models increased by only $4.6 \%, 4.5 \%$, and $6.6 \%$, respectively. This indicates that the rocking wall played the main role in the lateral bearing system. The moment frame was not able to restrain the rocking shear wall and was forced to rock along with it because of the high weight of the wall.

- On average, the inter-story displacement of the 3-, 9-, and 20-story HFR structures was $14.9 \%, 10.1 \%$ and $11.8 \%$ higher, respectively, than those of the MFR models. This related to the use of hinged connections, including the column-foundation connections and this increase was both predictable and justifiable.

- The global behavior of the relative displacement curves of the 3-, 9-, and 20-story models was similar. Again, this indicates that the behavior of the rocking concrete shear wall dominated because of the weight of the concrete wall and that the moment frame had no effect on the overall behavior of the structure, but only slightly reduced the relative displacement.

- The fixed connections in the moment frames were converted to hinged frames (gravity frames) in the 3-, 9-, and 20 -story structures. This reduced the amount of steel required for these structures by $40.2 \%, 42 \%$ and $47.7 \%$, respectively, compared to the MFR models because they were no longer designed to carry lateral loads. This led to a significant decrease in the weight of the structures, which resulted in a significant reduction in costs and an increase in cost-effectiveness.

- On average, the 3- and 20-story HFR models experienced $1.5 \%$ and $6.8 \%$ higher base shear, respectively, than the MFR models; however, the 9-story HFR model experienced 4.2\% less base shear than the MFR one which could be considered negligible. Also as stated above, the MFR models carried about $43.3 \%$ more weight than the HFR models on average. Therefore, it can be concluded that the HFR models with almost the same base shear amount and considerably less weight than the MFR models had greater capacity.

- On average, the rooftops' mass center of the 3- and 9-story HFR models experienced $15 \%$ and $9.8 \%$ more displacement, respectively, than the MFR models, while the 20 -story HFR model experienced $9.6 \%$ less displacement compared than the MFR model. In the high-rise structure, however, it was observed that the MFR model recorded less relative displacement than the HFR model, despite recording higher maximum rooftop displacement. This confirms that the MFR model for high-rise structures experienced more uniform inter-story displacement than the HFR model.

- Finally, this study concluded that for low- and mid-rise structures with rocking lateral load bearings, it is better to use hinged joints (HFR) instead of fixed ones (MFR), because although there was a slight increase in interstory drifts and rooftop displacements, using hinged joints minimized damages, prevented the formation of plastic hinges in connections, and with more capacity, significantly reduced the steel used in rocking structures and subsequently reduced the cost sharply.

- Both high-rise models were unable to easily return to their initial positions and the upper floors experienced more relative displacement that was exhibited as slowly drifting away from the centerline of the wall and kept rocking until they were eventually damped. The high amount of concrete used, the effect of the higher modes, weak energy dissipative devices, and dynamic characteristics of the structures could have contributed to this 
failure. In this case, according to this study, the use of rocking shear walls in high-rise structures is not recommended, unless a method is provided to control the upper floors of the structure. But in any case, the use of hinged joints in these structures is also preferred to the fixed joints due to their higher capacity and significantly less steel usage. It should be noted that a more optimal model for high-rise structures is being researched by the authors of this article.

\section{Declarations}

Ethical statements (The developed method is the original effort of the authors which is not submitted or published elsewhere)

Funding (This research was not funded by any funding bodies)

Conflicts of interest/Competing interests (The authors declare that they have no conflict of interest)

Availability of data and material (Data and material are available)

Code availability (The developed codes are available)

Authors' contributions (Conceptualization: [Ali Massumi, Mehrdad Piri]; Formal Analysis: [Mehrdad Piri]; Methodology: [Ali Massumi, Mehrdad Piri]; Validation: [Ali Massumi, Mehrdad Piri]; Writing - original draft: [Mehrdad Piri]; Writing - review \& editing: [Ali Massumi, Mehrdad Piri])

Plant Reproducibility (Not applicable)

Clinical Trials Registration (Not applicable)

Gels and Blots/ Image Manipulation (Not applicable)

High Risk Content (Not applicable)

\section{References}

Housner, G.W., The behavior of inverted pendulum structures during earthquakes. Bulletin of the seismological society of America, 1963. 53(2): p. 403-417.

Clough, R.W. and A.A. Huckelbridge, Preliminary experimental study of seismic uplift of a steel frame. 1977: Earthquake Engineering Research Center, College of Engineering, University ....

Huckelbridge, A.A. and R. Clough, Earthquake simulation tests of a nine story steel frame with columns allowed to uplift. 1977, University of California, Berkeley.

Priestley, M., R. Evison, and A. Carr, Seismic response of structures free to rock on their foundations. Bulletin of the New Zealand National Society for Earthquake Engineering, 1978. 11(3): p. 141-150.

Aslam, M., Earthquake rocking response of rigid bodies. 1978.

Meek, J., Dynamic response of tipping core buildings. Earthquake Engineering \& Structural Dynamics, 1978. 6(5): p. 437-454.

Yim, C.S., A.K. Chopra, and J. Penzien, Rocking response of rigid blocks to earthquakes. Earthquake Engineering \& Structural Dynamics, 1980. 8(6): p. 565-587.

Psycharis, I.N. and P.C. Jennings, Rocking of slender rigid bodies allowed to uplift. Earthquake Engineering \& Structural Dynamics, 1983. 11(1): p. 57-76.

Kurama, Y.C., Simplified seismic design approach for friction-damped unbonded post-tensioned precast concrete walls. Structural Journal, 2001. 98(5): p. 705-716.

Burtscher, S.L. and A. Dorfmann, Compression and shear tests of anisotropic high damping rubber bearings. Engineering structures, 2004. 26(13): p. 1979-1991. 
Hu, X., Y. Zhang, and N.S. Moghaddasi B, Seismic performance of reinforced concrete frames retrofitted with selfcentering hybrid wall. Advances in Structural Engineering, 2012. 15(12): p. 2131-2143.

Guo, T., G. Zhang, and C. Chen, Experimental study on self-centering concrete wall with distributed friction devices. Journal of Earthquake Engineering, 2014. 18(2): p. 214-230.

Mohammadi, M.H., A. Massumi, and A. Meshkat-Dini, Performance of RC moment frames with fixed and hinged supports under near-fault ground motions. Earthquakes and Structures, 2017. 13(1): p. 89-101.

Chen, C., et al., Study on the shear wall structure with combined form of replaceable devices. Advances in Structural Engineering, 2018. 21(9): p. 1327-1348.

Huang, X., Z. Zhou, and D. Zhu, Analytical investigation on lateral load responses of self-centering walls with distributed vertical dampers. Structural Engineering and Mechanics, 2019. 72(3): p. 000-000.

Hashemi, A. and P. Quenneville, Large-scale testing of low damage rocking Cross Laminated Timber (CLT) wall panels with friction dampers. Engineering Structures, 2020. 206: p. 110166.

Aragaw, L.F. and P.M. Calvi, Comparing the performance of traditional shear-wall and rocking shear-wall structures designed using the direct-displacement based design approach. Bulletin of Earthquake Engineering, 2020. 18(4): p. 1345-1369.

Li, X., et al., Shaking table test for externally-hung self-centering rocking wall structure. Bulletin of Earthquake Engineering, 2021. 19(2): p. 863-887.

Agency, F.E.M., State of the Art Report on Systems Performance of Steel Moment Frames Subject to Earthquake Ground Shaking (FEMA 355C). 2000, Taylor \& Francis Washington, DC.

Stanton, J.F. and C.W. Roeder, Elastomeric bearings design, construction, and materials. NCHRP report, 1982(248).

Kelly, J.M., Earthquake-resistant design with rubber. 1993.

Committee, A., Specification for structural steel buildings (ANSI/AISC 360-10). American Institute of Steel Construction, Chicago-Illinois, 2010.

Building and Housing Research Center. Iranian Code of Practice for seismic resistant design of buildings. Standard No. 2800, 4th edn. Building and Housing Research Center: Tehran, Iran, 1999. 